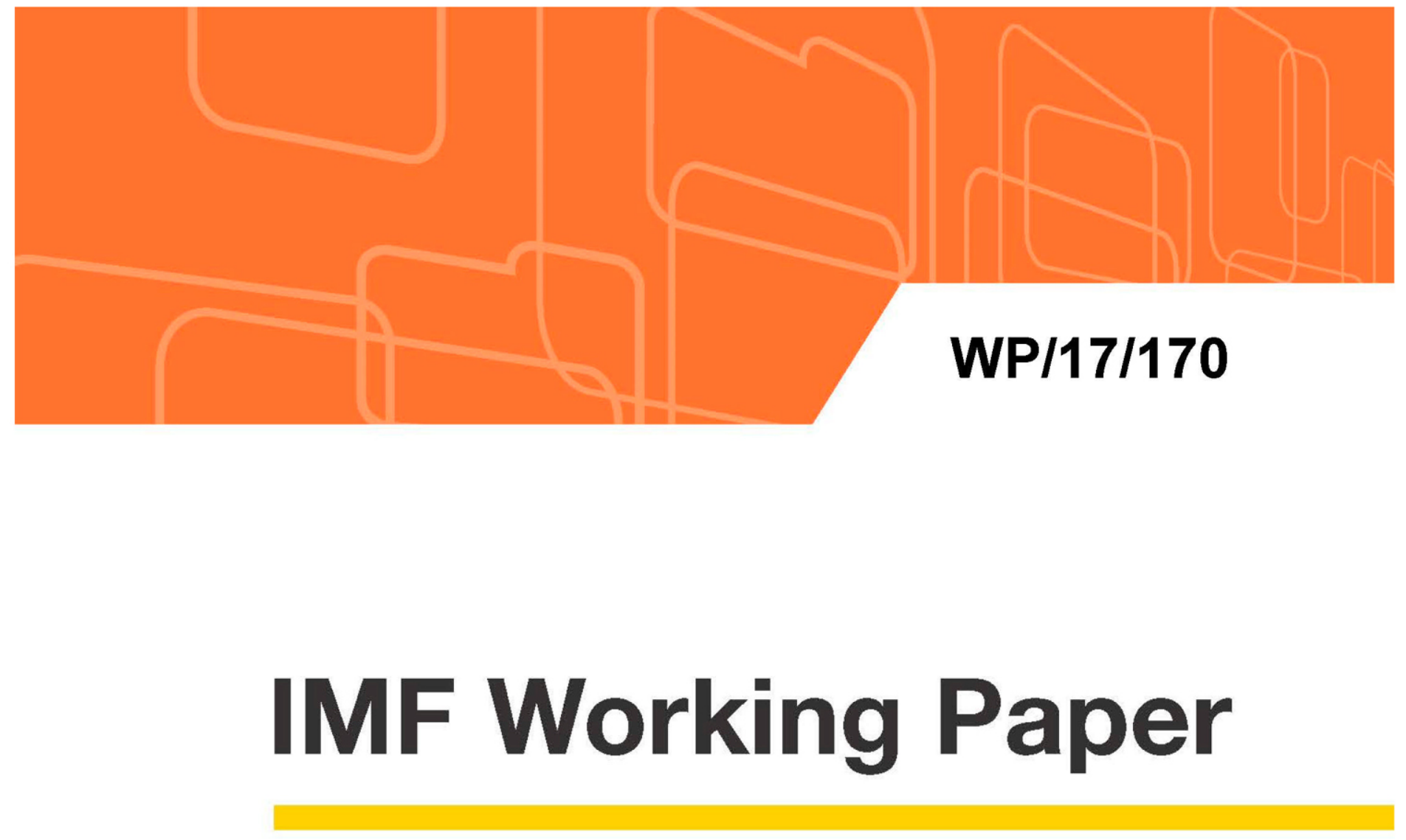

\title{
Macroprudential Policy Spillovers: A Quantitative Analysis
}

by Heedon Kang, Francis Vitek, Rina Bhattacharya, Phakawa Jeasakul, Sònia Muñoz, Naixi Wang, and Rasool Zandvakil

IMF Working Papers describe research in progress by the author(s) and are published to elicit comments and to encourage debate. The views expressed in IMF Working Papers are those of the author(s) and do not necessarily represent the views of the IMF, its Executive Board, or IMF management. 


\section{WP/17/170}

\section{IMF Working Paper}

\section{Macroprudential Policy Spillovers: A Quantitative Analysis}

by Heedon Kang, Francis Vitek, Rina Bhattacharya, Phakawa Jeasakul, Sònia Muñoz, Naixi Wang, and Rasool Zandvakil

IMF Working Papers describe research in progress by the author(s) and are published to elicit comments and to encourage debate. The views expressed in IMF Working Papers are those of the author(s) and do not necessarily represent the views of the IMF, its Executive Board, or IMF management. 


\title{
IMF Working Paper
}

Monetary and Capital Markets Department

\section{Macroprudential Policy Spillovers: A Quantitative Analysis \\ Prepared by Heedon Kang, Francis Vitek, Rina Bhattacharya, Phakawa Jeasakul, Sònia Muñoz, Naixi Wang, and Rasool Zandvakil ${ }^{1}$}

Authorized for distribution by Ulric Eriksson von Allmen

July 2017

IMF Working Papers describe research in progress by the author(s) and are published to elicit comments and to encourage debate. The views expressed in IMF Working Papers are those of the author(s) and do not necessarily represent the views of the IMF, its Executive Board, or IMF management.

\begin{abstract}
This paper analyzes cross-border macrofinancial spillovers from a variety of macroprudential policy measures, using a range of quantitative methods. Event study and panel regression analyses find that liquidity and sectoral macroprudential policy measures often affect cross-border bank credit, whereas capital measures do not. This empirical evidence is stronger for tightening than for loosening measures, is distributed across credit leakage and reallocation effects, and is generally regionally concentrated. Consistently, structural model based simulation analysis indicates that output and bank credit spillovers from sectoral macroprudential policy shocks are generally small worldwide, but are regionally concentrated and economically significant for countries connected by strong trade or financial linkages. This simulation analysis also indicates that countercyclical capital buffer adjustments have the potential to generate sizeable regional spillovers.
\end{abstract}

JEL Classification Numbers: F42; G21; G28

Keywords: Macroprudential policy; Macrofinancial spillovers; Event studies; Panel regressions; Structural models; Case studies

Author's E-Mail Addresses: HKang@imf.org; FVitek@imf.org; RBhattacharya@,imf.org; PJeasakul@imf.org; SMunoz@,imf.org; Naixi.Wang.mba2016@,said.oxford.edu; RZandvakil@imf.org

${ }^{1}$ The authors gratefully acknowledge comments and suggestions from Ulric Eriksson von Allmen, Dong He, Nigel Jenkinson, Erlend Nier, Inci Otker-Robe and Steven Phillips, as well as from seminar participants at the IMF. 


\section{Contents}

\section{INTRODUCTION}

IV. EMPIRICAL ANALYSIS

A. Transmission Channels

B. The Data

C. Event Study Analysis

D. Panel Regression Analysis

V. STRUCTURAL ANALYSIS

A. Transmission Channels

B. Simulation Results

C. Discussion

$\underline{32}$

VI. CONCLUSION

REFERENCES

\section{FIGURES}

1. Cross-Border Bank Credit Leakage and Reallocation Effects $\underline{9}$

2. Cross-Border Bank Credit Changes after Macroprudential Policy Tightening 13

3. Macroprudential Policy Tightening and Loosening Measures $\underline{14}$

4. Bilateral Bank Lending and Nonfinancial Private Sector Borrowing Exposures

5. Cluster Analysis of Bilateral Lending and Borrowing Networks

6. Impulse Responses to a Unit CCB Increase 27

7. Macrofinancial Spillovers from CCB Adjustments $\underline{28}$

8. Impulse Responses to a Unit MLTVL Reduction 29

9. Macrofinancial Spillovers from MLTVL Adjustments

10. Impulse Responses to a Unit CLTVL Reduction

11. Macrofinancial Spillovers from CLTVL Adjustments

12. Cross-Border Bank Loans from Advanced Europe to the CESEE Countries

13. Cross-Border Bank Loans from Sweden to the Baltic Countries

$\underline{37}$

\section{TABLES}

1. Event Shares and Two-Sample Proportion Test Results, Full Sample

2. Event Shares and Two-Sample Proportion Test Results, Excluding the GFC

3. Event Shares and Two-Sample Proportion Test Results, CESEE Countries

4. Hypothesis Test Results, Baseline Model Specification

5. Hypothesis Test Results, Full versus European Country Sample $1 \frac{12}{15}$

6. Hypothesis Test Results, Interactive Model Specification 
7. Panel Regression Variable Definitions $\underline{38}$

8. Panel Regression Estimation Results, Baseline Model Specification $\underline{39}$

9. Panel Regression Estimation Results, European Countries

10. Panel Regression Estimation Results, Interactive Model Specification $\underline{41}$

APPENDICES

I. Case Studies $\underline{34}$

II. Panel Regression Analysis

$\underline{38}$




\section{INTRODUCTION}

Macroprudential policy measures taken to promote financial stability in one regulatory jurisdiction can have macrofinancial effects on other jurisdictions, transmitted via international trade and financial linkages. The globalization of banking has intensified these international financial linkages, with global wholesale funding markets and cross-border bank lending being potentially powerful conduits for macroprudential policy spillover transmission via capital flows.

Macroprudential policy spillovers could be positive or negative. Building resilience in one country can reduce the risk of adverse financial spillovers to other jurisdictions, but resilience could also be built at the expense of stability in other jurisdictions. As discussed in IMF/FSB/BIS (2016), a macroprudential policy tightening measure taken to mitigate a domestic credit boom can unintentionally generate credit leakage or reallocation effects or both. As argued by Viñals and Nier (2014), these negative externalities from macroprudential policy measures can lead to inaction bias relative to the global optimum. If these spillovers are significant, then policymakers should consider them when addressing systemic risks.

As the use of macroprudential policy has grown, an empirical literature on the importance of cross-border macrofinancial spillovers has emerged, but the existing evidence is mixed. Overall, the empirical evidence suggests that the effect of macroprudential policy on crossborder bank credit is instrument type specific. Indeed, a recent collection of coordinated empirical studies documented in Buch and Goldberg (2016) concludes that there is greater evidence of cross-border bank credit spillovers from adjustments to liquidity or sectoral instruments than to capital instruments. But other empirical studies find partially contradictory results and a consensus has yet to be established.

The main contribution of this paper is the use, for the first time, of a range of quantitative methods to robustly analyze cross-border macrofinancial spillovers from a variety of macroprudential policy measures. These quantitative methods range from nonparametric event study analysis, to reduced-form panel regression analysis, to structural model based simulation analysis. Using a new database on macroprudential policy measures, our event study and panel regression analyses estimate the effects of adjustments to capital, liquidity and sectoral macroprudential policy instruments on cross-border bank credit. They also distinguish between tightening versus loosening measures, as well as credit leakage versus reallocation effects. Our structural model based simulation analysis quantifies bank credit and output spillovers from shocks to specific capital and sectoral macroprudential policy instruments.

These alternative quantitative methods are complementary. The empirical methods rely on weaker identifying restrictions to estimate the statistical significance of specific macroprudential policy spillover effects, while the structural method imposes stronger 
identifying restrictions to estimate the economic significance of complete macroprudential policy spillover transmission mechanisms.

In broad agreement with the existing empirical literature, our event study and panel regression analyses indicate that macroprudential policy measures targeted at the composition of banks' funding or the indebtedness of specific sectors often have statistically significant effects on cross-border bank credit, whereas measures targeted at the level or quality of banks' capital buffers do not. In general, this empirical evidence of the existence of cross-border macroprudential policy spillovers is stronger for tightening than for loosening measures, and is regionally concentrated.

Broadly consistent with these empirical results, our structural model-based simulation analysis indicates that macrofinancial spillovers from sectoral macroprudential policy shocks are generally small worldwide, but are regionally concentrated, and are occasionally economically significant. This simulation analysis also indicates that adjustments in the countercyclical capital buffer have the potential to generate sizeable regional spillovers.

The organization of this paper is as follows. Key concepts are discussed in Section II, while the literature on cross-border macroprudential policy spillovers is reviewed in Section III. Event study and panel regression analyses of cross-border bank credit spillovers from macroprudential policy measures are conducted in Section IV, with a reference to case studies presented in Appendix I. A structural model based analysis of macrofinancial spillovers from macroprudential policy shocks is conducted in Section V. Finally, Section VI concludes.

\section{KEY CONCEPTS}

The objective of macroprudential policy is to mitigate systemic risk, which encompasses events that if realized could impair the capacity of the financial system to intermediate credit. As discussed in IMF (2014a), macroprudential policy aims to reduce the frequency and severity of financial crises by mitigating systemic risk.

We define macroprudential policy measures as adjustments to macroprudential policy instrument settings, generally in response to systemic risk. In principle, adjustments to any macroprudential policy instrument that bind on borrowers or lenders may be expected to have domestic macrofinancial effects by altering the size or composition of credit, given incompletely offsetting responses by other borrowers or lenders. These domestic macrofinancial effects may in turn be transmitted abroad through spillovers - and reverberate back to the domestic economy as spillbacks - via combinations of international trade and financial linkages. These international financial linkages may be direct, through cross-border balance sheet exposures, or indirect in the form of contagion effects. 
Countries use an array of macroprudential policy instruments to mitigate systemic risk. In this paper we classify the macroprudential policy instruments under consideration according to their function: (i) capital instruments used to manage the level or quality of banks' capital buffers to safeguard their solvency (time-varying capital requirements, dynamic loan-loss provisions, profit distribution restrictions, countercyclical capital buffers); (ii) liquidity instruments used to manage the composition of banks' funding to safeguard their liquidity (loan-to-deposit ratio limits, maturity mismatch limits, net open foreign exchange position limits, reserve requirements); and (iii) sectoral instruments used to control the indebtedness of specific sectors to reduce default risk (loan-to-value ratio limits, debt-service-to-income ratio limits, debt-to-income or loan-to-income ratio limits, quantitative loan restrictions). ${ }^{2}$ As discussed in IMF (2014b), these capital and liquidity instruments impose constraints on lenders, whereas the sectoral instruments apply to borrowers.

The literature on macroprudential policy spillovers has focused on cross-border bank credit effects. These spillover effects may be expected to arise largely from the behavioral responses of borrowers or lenders to changes in the financial regulatory environment. They include credit leakage and reallocation effects. Cross-border credit leakage effects are spillbacks that arise when domestic borrowers substitute their demand for credit from domestic lenders to foreign lenders in response to a tightening of domestic macroprudential policy, and vice versa for a loosening. In contrast, cross-border credit reallocation effects are outward spillovers that arise when domestic lenders switch their supply of credit from domestic borrowers to foreign borrowers in response to domestic macroprudential policy tightening, and vice versa for a loosening. In what follows, we simply refer to all of these cross-border bank credit effects as spillovers.

While this paper focuses on cross-border macroprudential policy spillovers, macroprudential policy measures may also generate macrofinancial spillovers within a regulatory jurisdiction, by incentivizing the migration of credit intermediation in or out of the relevant regulatory perimeter, as discussed in Cizel and others (2016). ${ }^{3}$ The failure to take macroprudential policy measures when warranted may also generate cross-border negative externalities, should this result in the realization of systemic risk. However, the quantification of such effects is also beyond the scope of this paper.

\section{LITERATURE REVIEW}

A burgeoning recent empirical literature on cross-border macroprudential policy spillovers reports mixed results. Consistent with the results of our empirical analysis, recent studies find that cross-border bank credit spillovers are more likely to arise from adjustments to liquidity

\footnotetext{
${ }^{2}$ In this paper we analyze macrofinancial spillovers from countercyclical capital buffer adjustments only using structural analysis, given insufficient historical observations to facilitate empirical analysis.

${ }^{3}$ The empirical analysis of Cizel and others (2016) finds evidence that credit intermediation shifts from banks to nonbanks when macroprudential policy tightening measures are imposed on banks.
} 
or sectoral instruments than to capital instruments. But other empirical studies find partially contradictory results.

Several empirical studies find that international differences in bank regulation in general, or in macroprudential policy in particular, are associated with cross-border credit leakage or reallocation effects. To examine whether international differences in financial regulation affect cross-border bank credit, Houston, Lin and Ma (2012) use a panel data set covering 301 banks with headquarters across 26 countries over the period 1996 to 2007 . They find evidence of credit reallocation effects from international differences in financial regulation, including with respect to bank capital requirements. To analyze the overall effectiveness of macroprudential policy, Cerutti, Claessens and Laeven (2015) use a panel data set covering 12 instruments for 119 countries over the period 2000 to 2013 . They find that macroprudential policy tightening is associated with lower domestic credit but higher crossborder borrowing, indicative of credit leakage effects, particularly in more financially developed and open economies.

A recent collection of coordinated empirical studies finds that cross-border bank credit spillovers are more likely to arise from adjustments to liquidity or sectoral instruments than to capital instruments. Pooling the results of 15 country-specific and 2 international studies using panel data sets covering individual banks over the period 2000Q1 to 2014Q4, Buch and Goldberg (2016) analyze the effects of a variety of macroprudential policy measures on domestic and cross-border bank credit. They find that adjustments to liquidity or sectoral instruments are more likely to affect cross-border bank credit than are adjustments to capital instruments. The intensity of these generally small effects varies systematically across banks according to their balance sheet conditions and business models.

However, other empirical studies find partially contradictory results. For example, Aiyar and others (2014) examine whether a rise in minimum capital requirements on United Kingdom banks reduces their cross-border lending, using a panel data set covering many individual banks and countries over the period 1999Q1 to 2006Q4. They estimate that a one percentage point capital requirement increase is associated with a reduction in cross-border bank lending growth of 5.5 percentage points, primarily transmitted to foreign banks as opposed to foreign borrowers.

Similarly, Akinci and Olmstead-Rumsey (2015) conduct an empirical analysis on the effectiveness of macroprudential policy, using a panel data set covering 7 instruments for 57 countries over the period 2000Q1 to 2013Q4. They find that macroprudential policy tightening using capital and sectoral instruments significantly reduces domestic bank credit, but not total credit, indicative of credit leakage effects. Moreover, Reinhardt and Sowerbutts (2015) analyze whether macroprudential policy measures affect cross-border bank credit, using a panel data set covering 37 countries over the period 2005Q1 to 2014Q3. They find evidence of credit leakage effects associated with the use of capital instruments, mixed evidence for liquidity instruments, and no evidence for sectoral instruments. 
Theoretical studies of cross-border spillovers from macroprudential policy measures are scarce, and more research is needed in this area to better understand the results of empirical studies. Based on a conceptual framework for analyzing cross-border macroprudential policy spillovers, Fahr and Zochowski (2015) hypothesize that: (i) capital measures can affect the provision of cross-border bank credit to households and firms, by incentivizing changes in the size or composition of banks' loan portfolios; (ii) liquidity measures can also affect crossborder bank credit, by altering interbank lending; and (iii) sectoral measures are less likely to affect cross-border bank credit, given limited circumvention opportunities. Within the framework of a two-country model of systemic liquidity risk taking, Bengui (2012) analyzes the desirability of coordinating financial regulation internationally. His analysis predicts that domestic macroprudential policy tightening using liquidity instruments shifts bank funding risk abroad.

\section{EMPIRICAL ANALYSIS}

We employ two alternative empirical methods: nonparametric event study analysis and reduced-form panel regression analysis. Our event study analysis estimates the impact of macroprudential policy measures on domestic versus cross-border bank credit growth, relying only on timing and sign restrictions to achieve identification. Our panel regression analysis estimates bilateral cross-border bank credit growth spillovers from macroprudential policy measures, achieving identification by controlling for other push-pull factors that may also drive these capital flows, while using instrumental variables to correct for endogeneity bias.

\section{A. Transmission Channels}

Our empirical analysis focuses on both cross-border bank credit leakage and reallocation effects of macroprudential policy measures. As depicted in Figure 1, a credit leakage effect occurs when a macroprudential policy tightening (loosening) measure, that decreases (increases) bank credit in the recipient country, also increases (decreases) borrowing from foreign banks - either on a direct cross-border basis or via their domestic branches if the latter are exempt from the policy measure. In contrast, a credit reallocation effect arises when a macroprudential policy tightening (loosening) measure, that decreases (increases) bank credit in the source country, also increases (decreases) cross-border lending to foreign borrowers.

An increase in cross-border lending can arise when banks rebalance the international composition of their loan portfolios in response to a macroprudential policy tightening measure imposed on an unconsolidated basis. But a reduction in cross-border lending can also arise when the macroprudential policy tightening measure is applied to banks on a consolidated basis. 
Figure 1. Cross-Border Bank Credit Leakage and Reallocation Effects

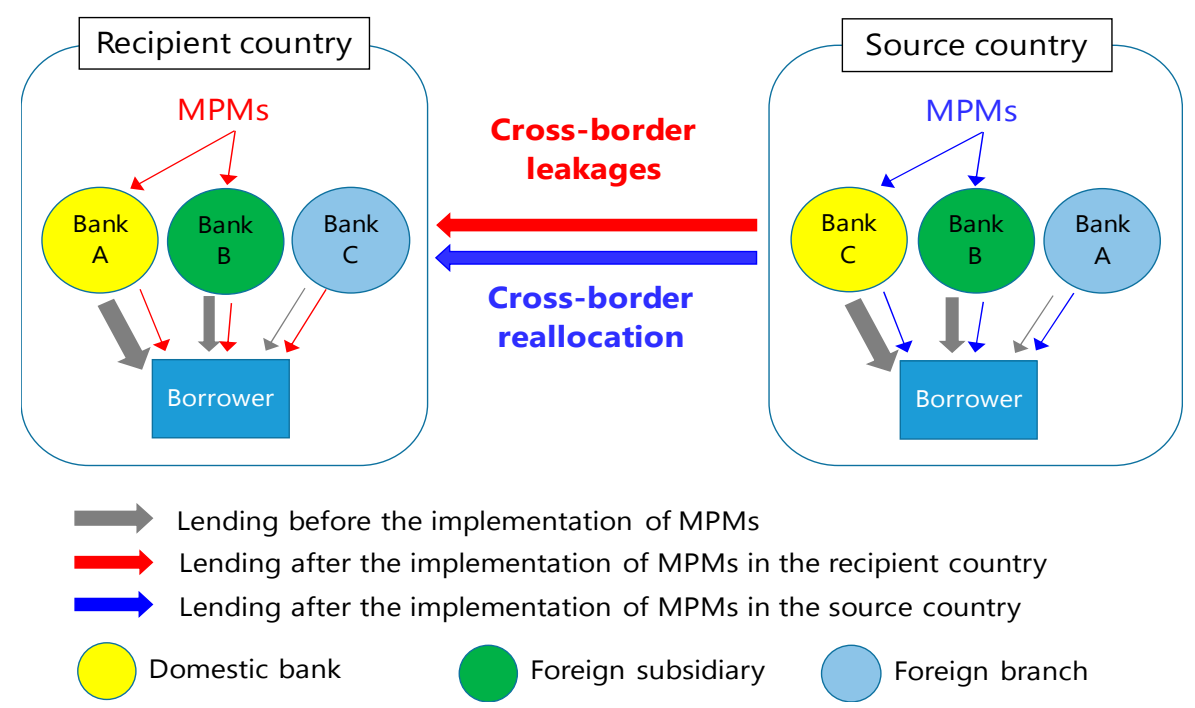

Source: IMF Staff.

\section{B. The Data}

Our panel data set consists of observations on multiple bank credit measures, macroprudential policy measure indices, and macrofinancial control variables. It covers 64 countries over the period 2000Q1 to 2015Q1. ${ }^{4}$

\section{Bank Credit}

We use domestic bank credit, cross-border bank lending and borrowing, and directional bilateral cross-border bank credit data obtained from the International Banking Statistics database compiled by the Bank for International Settlements (BIS). Since macroprudential policy is generally applied at the national level to domestically regulated banks - generally including the subsidiaries but excluding the branches of foreign banks operating domestically - we use locational cross-border bank credit data. We focus on bank assets in the form of loans, excluding securities and other claims that are not directly subject to the macroprudential policy measures under consideration.

The locational banking statistics are based on the residency principle, under which the unconsolidated aggregate credit exposures of all banks operating in a regulatory jurisdiction are reported, irrespective of the jurisdiction in which the associated banking group is

\footnotetext{
${ }^{4}$ The geographically and economically diverse set of countries consists of Argentina, Australia, Austria, Belgium, Brazil, Bulgaria, Canada, Chile, China, Colombia, Croatia, the Czech Republic, Denmark, Estonia, Finland, France, Germany, Greece, Hong Kong SAR, Hungary, Iceland, India, Indonesia, Ireland, Israel, Italy, Japan, Korea, Kuwait, Latvia, Lebanon, Lithuania, Luxembourg, Malaysia, Malta, Mexico, Mongolia, the Netherlands, New Zealand, Nigeria, Norway, Peru, the Philippines, Poland, Portugal, Romania, Russia, Saudi Arabia, Serbia, Singapore, the Slovak Republic, Slovenia, South Africa, Spain, Sweden, Switzerland, Thailand, Turkey, Ukraine, the United Arab Emirates, the United Kingdom, the United States, Uruguay, and Vietnam.
} 
incorporated. This is consistent with balance of payments and external debt data reporting principles, and therefore with the definitions of our macroprudential policy measure indices and macrofinancial control variables.

\section{Macroprudential Policy}

To facilitate our empirical analysis, we construct a new database on macroprudential policy measures, covering those 11 instruments most frequently used over the period $2000 \mathrm{Q} 1$ to 2015Q1. This database is based on the survey conducted by Lim and others (2013), extended to incorporate information reported on authorities' websites, as well as data obtained from the Bank for International Settlements and the European Systemic Risk Board. ${ }^{5}$

For our empirical analysis, we classify the 11 macroprudential policy instruments covered by our database both by function and target agent. The functional categories are capital instruments (time-varying capital requirements, dynamic loan-loss provisions, profit distribution restrictions), liquidity instruments (loan-to-deposit ratio limits, maturity mismatch limits, net open foreign exchange position limits, reserve requirements), and sectoral instruments (loan-to-value ratio limits, debt-service-to-income ratio limits, debt-toincome or loan-to-income ratio limits, quantitative loan restrictions). As mentioned earlier, the target agents are lenders (capital instruments, liquidity instruments) and borrowers (sectoral instruments). ${ }^{6}$

We aggregate our data on macroprudential policy measures observed for these 11 instruments into country-specific and time-varying indices. To estimate whether the effects of macroprudential policy measures are asymmetric, we differentiate between tightening versus loosening measures. Moreover, we disaggregate our total macroprudential policy tightening and loosening indices into sub-indices classified by function and target agent.

The indices and sub-indices are all indicator variables, which equal one if at least one macroprudential policy instrument in the given category is tightened or loosened at least once during the quarter under consideration, and zero otherwise. This aggregation scheme captures information regarding the direction, but not the size, of macroprudential policy instrument adjustments. This loss of information through aggregation is unavoidable, as different instruments have different macrofinancial effects per unit change, as well as different units of measurement.

\footnotetext{
5 There is an ongoing project to merge this database with the IMF's Global Macroprudential Instruments database, to provide more granular coverage of macroprudential policy measures for more countries.

${ }^{6}$ We do not consider capital flow management instruments, such as taxes on current or capital account transactions.
} 


\section{Event Study Analysis}

Our event study analysis examines whether macroprudential policy tightening (loosening) measures are associated with both (i) a decrease (increase) in domestic bank credit growth and (ii) an increase (decrease) in cross-border bank credit growth. To focus on persistent cross-border bank credit spillovers, we require that these sign restrictions be satisfied for at least two consecutive quarters on a year-over-year basis.

\section{Methodology}

Let $I_{i, t}^{L^{+}}$or $I_{i, t}^{R^{+}}$denote an indicator variable that equals one if and only if a positive crossborder bank credit leakage or reallocation event occurs, respectively in country $i$ at time $t$ :

$$
\begin{gathered}
I_{i, t}^{L^{+}}=1 \text { if }\left\{\Delta_{4} c_{i, t}>\Delta_{4} c_{i, t+1}>\Delta_{4} c_{i, t+2} \text { and } \Delta_{4} c_{i, t}^{d, \text { row }}<\Delta_{4} c_{i, t+1}^{d, \text { row }}<\Delta_{4} c_{i, t+2}^{d, \text { row }}\right\}, \\
I_{i, t}^{R^{+}}=1 \text { if }\left\{\Delta_{4} c_{i, t}>\Delta_{4} c_{i, t+1}>\Delta_{4} c_{i, t+2} \text { and } \Delta_{4} c_{i, t}^{s, r \text { row }}<\Delta_{4} c_{i, t+1}^{\text {s,row }}<\Delta_{4} c_{i, t+2}^{s, r o w}\right\} .
\end{gathered}
$$

Here $\Delta_{4} c_{i, t}$ denotes the quarterly year-over-year growth rate of domestic bank credit, $\Delta_{4} c_{i, t}^{d, \text { row }}$ denotes the quarterly year-over-year growth rate of cross-border borrowing from foreign banks, and $\Delta_{4} c_{i, t}^{s, r o w}$ denotes the quarterly year-over-year growth rate of cross-border lending by domestic banks. In parallel, let $I_{i, t}^{L^{+}, k^{+}}$or $I_{i, t}^{R^{+}, k^{+}}$denote an indicator variable that equals one if and only if a positive credit leakage or reallocation event occurs, coincident with a macroprudential policy tightening event for instrument type $k$, respectively in country $i$ at time $t$ :

$$
\begin{aligned}
& I_{i, t}^{L^{+}, k^{+}}=1 \text { if }\left\{I_{i, t}^{L^{+}}=1 \text { and } I_{i, t}^{k^{+}}=1\right\}, \\
& I_{i, t}^{R^{+}, k^{+}}=1 \text { if }\left\{I_{i, t}^{R^{+}}=1 \text { and } I_{i, t}^{k^{+}}=1\right\} .
\end{aligned}
$$

Here $I_{i, t}^{k^{+}}$denotes an indicator variable that equals one if and only if a macroprudential policy tightening event occurs for instrument type $k$ in country $i$ at time $t$. Our panel data set covers $N=64$ countries and $T=61$ time periods, implying a total of $N T=3,904$ observations.

Let $s^{L^{+}}$and $s^{R^{+}}$denote the sample proportions of unconditional positive credit leakage and reallocation events, respectively:

$$
s^{L^{+}}=\frac{1}{N T} \sum_{i=1}^{N} \sum_{t=1}^{T} I_{i, t}^{L^{+}}, s^{R^{+}}=\frac{1}{N T} \sum_{i=1}^{N} \sum_{t=1}^{T} I_{i, t}^{R^{+}} .
$$

In parallel, let $s^{L^{+}, k^{+}}$and $s^{R^{+}, k^{+}}$denote the sample proportions of positive credit leakage and reallocation events, conditional on macroprudential policy tightening events for instrument type $k$, respectively: 


$$
s^{L^{+}, k^{+}}=\frac{\sum_{i=1}^{N} \sum_{t=1}^{T} I_{i, t}^{L^{+}, k^{+}}}{\sum_{i=1}^{N} \sum_{t=1}^{T} I_{i, t}^{k^{+}}}, s^{R^{+}, k^{+}}=\frac{\sum_{i=1}^{N} \sum_{t=1}^{T} I_{i, t}^{R^{+}, k^{+}}}{\sum_{i=1}^{N} \sum_{t=1}^{T} I_{i, t}^{k^{+}}} .
$$

We perform a two-sample proportions test of the null hypothesis that the unconditional and conditional proportions are equal, versus the one-sided alternative hypothesis that the conditional proportion exceeds the unconditional proportion:

$$
\begin{gathered}
H_{0}^{L^{+}}: s^{L^{+}, k^{+}}=s^{L^{+}} \text {vs } H_{1}^{L^{+}}: s^{L^{+}, k^{+}}>s^{L^{+}}, \\
H_{0}^{R^{+}}: s^{R^{+}, k^{+}}=s^{R^{+}} \text {vs } H_{1}^{R^{+}}: s^{R^{+}, k^{+}}>s^{R^{+}} .
\end{gathered}
$$

We follow a parallel hypothesis testing procedure for macroprudential policy loosening measures, with all signs reversed in the corresponding indicator variable definitions.

\section{Results}

Our event study indicates that macroprudential policy tightening measures using liquidity or sectoral instruments are associated with statistically significant credit leakage and reallocation effects, as reported in Table 1. Macroprudential policy tightening measures using liquidity and sectoral instruments are associated with lower domestic bank credit growth, higher growth in cross-border borrowing from foreign banks, and higher growth in domestic banks' cross-border lending to foreign borrowers. ${ }^{7}$ However, we find little or no evidence of credit spillovers from macroprudential policy tightening measures using capital instruments, perhaps because some of them are imposed on a consolidated basis. Moreover, we find little

\begin{tabular}{|c|c|c|c|c|}
\hline \multicolumn{5}{|c|}{ (Percent, 2000Q1-2015Q1) } \\
\hline \multirow[b]{2}{*}{ Unconditional } & & Cross-border reallocation & Cross-border leakage & Events \\
\hline & & 16.4 & 16.3 & 3904 \\
\hline \multirow{6}{*}{$\begin{array}{l}\text { Conditional on } \\
\text { macroprudential } \\
\text { policy tightening }\end{array}$} & All instruments & 22.1 & 21.0 & 376 \\
\hline & Capital & 16.5 & 21.1 & 133 \\
\hline & Liquidity & 23.2 & 21.5 & 177 \\
\hline & Sectoral & 26.1 & 24.4 & 119 \\
\hline & Lenders & 20.4 & 21.1 & 278 \\
\hline & Borrowers & 26.1 & 24.4 & 117 \\
\hline \multirow[b]{2}{*}{ Unconditional } & & Cross-border reallocation & Cross-border leakage & Events \\
\hline & & 14.7 & 17.1 & 3904 \\
\hline \multirow{6}{*}{$\begin{array}{l}\text { Conditional on } \\
\text { macroprudential } \\
\text { policy loosening }\end{array}$} & All instruments & 13.9 & 16.5 & 231 \\
\hline & Capital & 12.1 & 24.2 & 33 \\
\hline & Liquidity & 13.6 & 15.9 & 176 \\
\hline & Sectoral & 19.4 & 13.9 & 36 \\
\hline & Lenders & 13.0 & 16.5 & 200 \\
\hline & Borrowers & 19.4 & 13.9 & 36 \\
\hline
\end{tabular}
or no evidence of spillovers from any macroprudential policy loosening measures.

Table 1. Event Shares and Two-Sample Proportion Test Results, Full Sample

Source: IMF staff estimates.

Note: Significance at the 1,5 and 10 percent levels is indicated by red, orange and yellow respectively.

\footnotetext{
${ }^{7}$ Reserve requirements — which have been the most frequently used liquidity instrument—apply to the domestic liabilities of banks on an unconsolidated basis.
} 
These spillovers from macroprudential policy tightening measures using liquidity or sectoral instruments are also economically significant. On average, cross-border bank borrowing or lending grew 2 to 4 percentage points faster within two quarters of macroprudential policy tightening measures using liquidity or sectoral instruments, as depicted in Figure 2. In contrast, cross-border bank borrowing or lending grew 2 to 5 percentage points slower within two quarters after macroprudential policy tightening occurred using capital instruments.

Figure 2. Cross-Border Bank Credit Changes after Macroprudential Policy Tightening

(Median Changes in Quarterly Year-Over-Year Growth Rates)
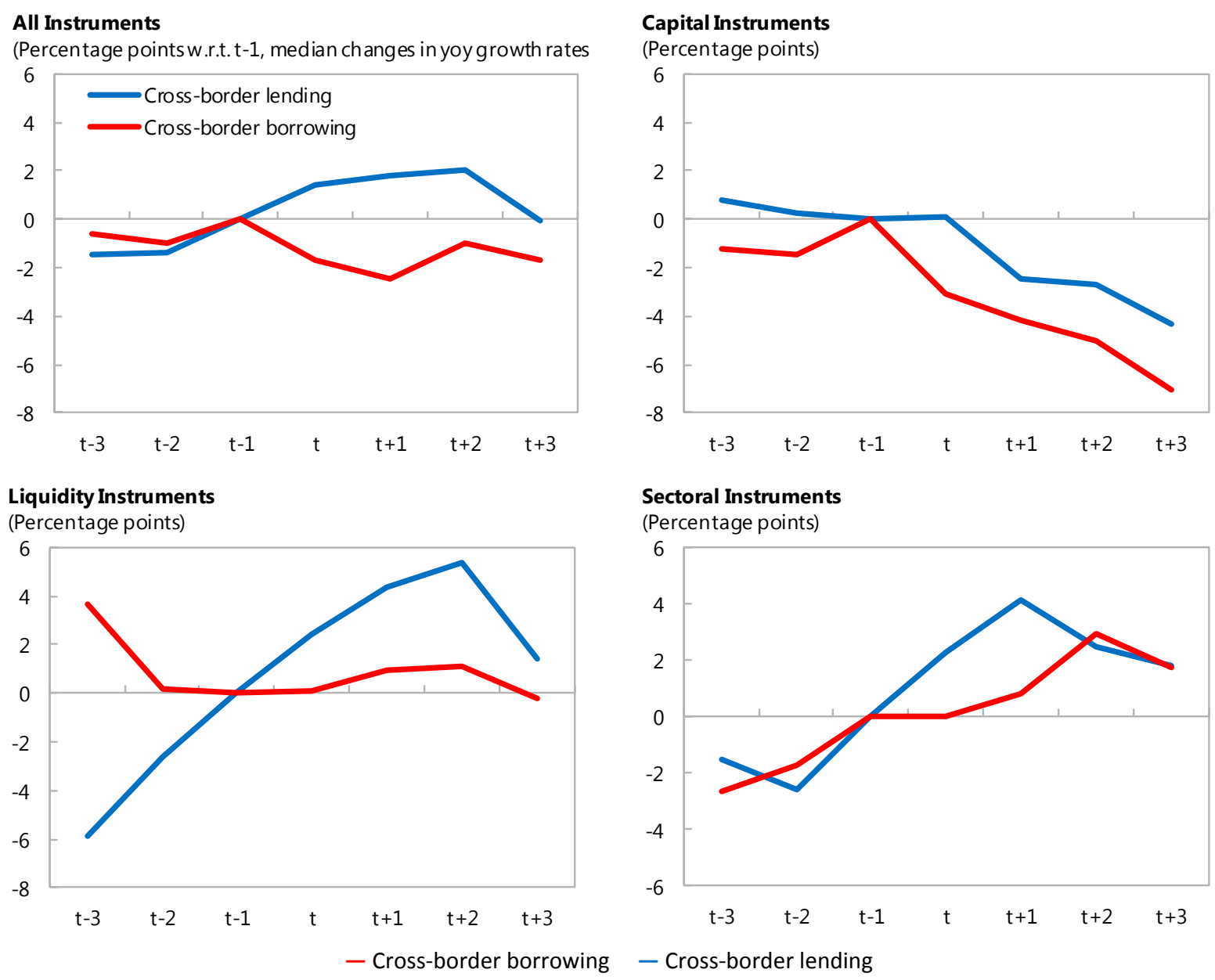

Sources: BIS International Banking Statistics database and IMF staff calculations.

\section{Robustness}

To check whether the results of our event study are robust to changes in the coverage of our panel data set, we repeat our analysis for economically meaningful subsamples. In particular, we exclude the Global Financial Crisis (GFC) period of 2008Q1 to 2012Q4, during which dramatic deleveraging by global banks concentrated on their cross-border lending may confound our statistical inference. We also focus on the Central, Eastern and Southeastern 
European (CESEE) countries, given their exceptionally high cross-border borrowing from foreign banks during the build-up to the GFC. ${ }^{8}$

\section{Exclusion of the GFC Period}

At the height of the GFC in 2008Q4, there was a spike in the global incidence of macroprudential policy loosening measures as systemic risk was realized, as depicted in Figure 3. During the recovery from the GFC, the global incidence of macroprudential policy tightening measures was elevated, reflecting the more active use of macroprudential policy instruments in many countries.

\section{Figure 3. Macroprudential Policy Tightening and Loosening Measures}
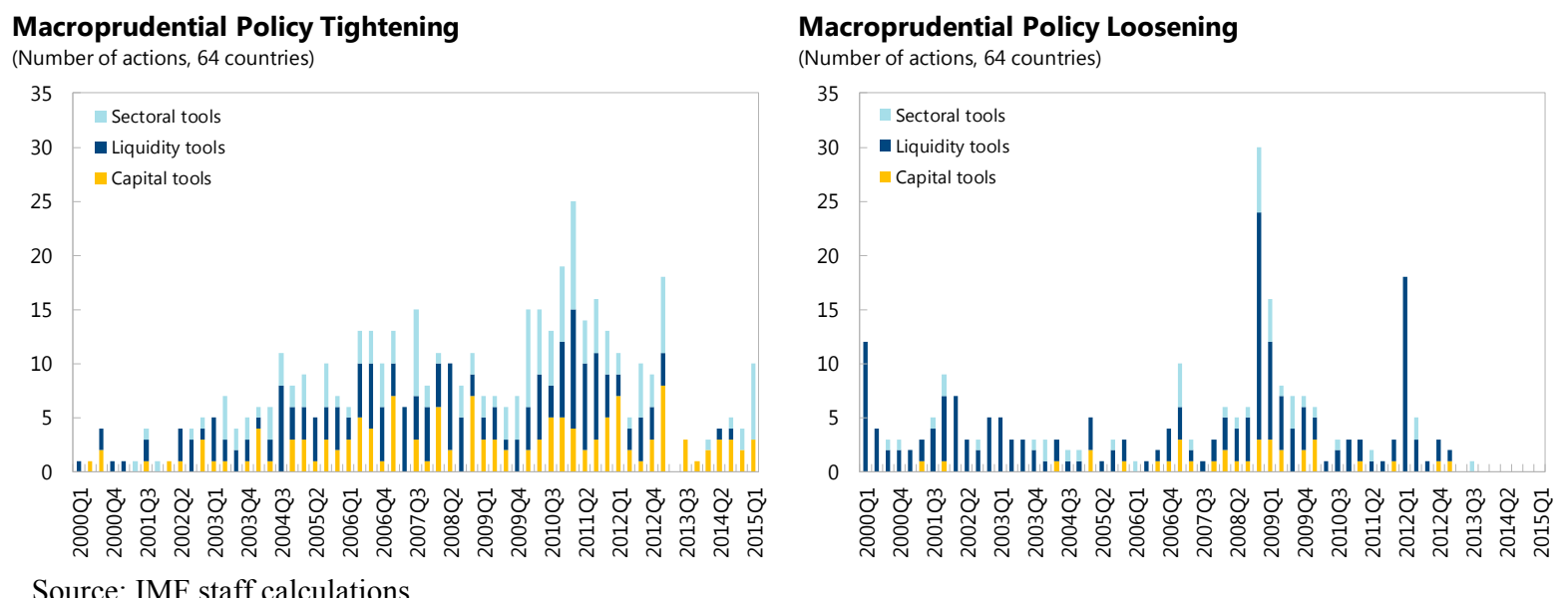

Repeating our event study analysis excluding the GFC period - which almost halves the number of macroprudential policy tightening and loosening events under considerationyields broadly consistent results to those obtained based on the full sample. The main difference is that there is now evidence of credit leakage effects from macroprudential policy loosening measures using capital instruments, associated with higher domestic bank credit growth and lower growth in cross-border borrowing from foreign banks at the 1 percent level, as reported in Table 2.

\footnotetext{
${ }^{8}$ The CESEE countries under consideration are Bulgaria, Croatia, the Czech Republic, Hungary, Poland, Romania, and the Slovak Republic.
} 
Table 2. Event Shares and Two-Sample Proportion Test Results, Excluding the GFC

(Percent, 2000Q1-2007Q4 and 2013Q1-2015Q1)

\begin{tabular}{|c|c|c|c|c|}
\hline \multirow[b]{2}{*}{ Unconditional } & & Cross-border reallocation & Cross-border leakage & Events \\
\hline & & 14.0 & 12.2 & 2880 \\
\hline \multirow{6}{*}{$\begin{array}{l}\text { Conditional on } \\
\text { macroprudential } \\
\text { policy tightening }\end{array}$} & All instruments & 21.1 & 19.1 & 199 \\
\hline & Capital & 15.1 & 12.3 & 73 \\
\hline & Liquidity & 22.8 & 20.7 & 92 \\
\hline & Sectoral & 28.1 & 26.3 & 57 \\
\hline & Lenders & 19.2 & 17.2 & 151 \\
\hline & Borrowers & 28.1 & 26.3 & 55 \\
\hline \multirow[b]{2}{*}{ Unconditional } & & Cross-border reallocation & Cross-border leakage & Events \\
\hline & & 14.0 & 16.3 & 2880 \\
\hline \multirow{6}{*}{$\begin{array}{l}\text { Conditional on } \\
\text { macroprudential } \\
\text { policy loosening }\end{array}$} & All instruments & 13.0 & 22.6 & 115 \\
\hline & Capital & 14.3 & 42.9 & 14 \\
\hline & Liquidity & 11.2 & 20.2 & 89 \\
\hline & Sectoral & 23.5 & 23.5 & 17 \\
\hline & Lenders & 11.2 & 22.4 & 98 \\
\hline & Borrowers & 23.5 & 23.5 & 17 \\
\hline
\end{tabular}

Source: IMF staff estimates.

Note: Significance at the 1,5 and 10 percent levels is indicated by red, orange and yellow respectively.

\section{Focus on the CESEE Countries}

Focusing on the CESEE countries, we find stronger evidence of credit leakage effects from macroprudential policy tightening measures using capital or sectoral instruments than was obtained using the full sample. As reported in Table 3, macroprudential policy tightening measures using capital and sectoral instruments are associated with lower domestic bank credit growth and higher growth in cross-border borrowing from foreign banks at the 1 percent level. While this evidence of spillovers from sectoral instruments is consistent with our full sample results, the evidence for capital and liquidity instruments is not.

Table 3. Event Shares and Two-Sample Proportion Test Results, CESEE Countries

(Percent, 2000Q1-2015Q1)

\begin{tabular}{llcc}
\hline \multirow{2}{*}{ Unconditional } & & Cross-border leakage & Events \\
\cline { 3 - 4 } & & 17.8 & 455 \\
\hline \multirow{3}{*}{ Conditional on } & All instruments & 32.8 & 58 \\
\cline { 2 - 4 } macroprudential & Capital & 41.7 & 24 \\
policy tightening & Liquidity & 23.8 & 21 \\
& Sectoral & 40.9 & 22 \\
\cline { 2 - 4 } & Lenders & 33.3 & 42 \\
& Borrowers & 40.9 & 22 \\
\hline \hline \multirow{3}{*}{ Unconditional } & & Cross-border leakage & Events \\
\hline \multirow{4}{*}{ Conditional on } & All instruments & 16.3 & 455 \\
macroprudential & Capital & 26.2 & 42 \\
policy loosening & Liquidity & 33.3 & 3 \\
& Sectoral & 24.3 & 37 \\
\cline { 2 - 4 } & Lenders & 25.0 & 4 \\
\hline \hline
\end{tabular}

Source: IMF staff estimates.

Note: Significance at the 1, 5 and 10 percent levels is indicated by red, orange and yellow respectively. 
As discussed in our case study on the CESEE countries in Annex I, prior to the GFC, macroprudential policy tightening measures were partially circumvented through borrowing from foreign banks and domestic nonbanks. For example, as macroprudential policy was tightened in Bulgaria and Croatia, borrowing from foreign banks accelerated rapidly. As these circumvention tactics became known, the authorities tackled them by widening the regulatory perimeter to limit regulatory arbitrage opportunities. Similarly, as discussed in our case study on the Baltic countries in Annex I, during the decade prior to the GFC these countries experienced credit booms largely financed by capital inflows from Swedish banks. These large capital inflows resulted in the accumulation of systemic risk in the Baltic countries, and their macroprudential policy tightening responses were ineffective at reducing credit growth.

\section{Caveats}

Our event study analysis does not associate changes in domestic versus cross-border bank credit growth with factors other than macroprudential policy measures, relying only on timing and sign restrictions to identify credit leakage and reallocation effects. To estimate the partial effects of macroprudential policy measures on directional bilateral cross-border bank credit growth while controlling for a variety of other push-pull factors, we turn to panel regression analysis.

\section{Panel Regression Analysis}

Our panel regression analysis further examines whether instrument-type specific macroprudential policy tightening or loosening measures in recipient (source) countries are associated with cross-border bank credit leakage (reallocation) effects.

\section{Specification}

The specification of our panel regression model linking directional bilateral cross-border bank credit growth to macroprudential policy measures is motivated by the gravity model of international trade. Under the gravity model in Bergstrand (1985) and Deardorff (1998), total nominal trade between two countries is directly proportional to their economic sizesusually measured by nominal output - and is inversely proportional to their trade distance, which often depends on their geographical proximity and trade restrictions. Under our adaptation of this gravity model to international finance, bilateral cross-border bank credit between two countries is directly proportional to the size of their financial systems - proxied by measures of bank credit demand and supply - and is inversely proportional to their financial distance, which depends on macroprudential policy tightness among other factors.

There exists empirical evidence supporting applications of the gravity model to international finance. Portes and Rey (2005) find that bilateral cross-border equity portfolio investment 
flows depend on equity market size in the recipient and source countries, as well as on financial transaction costs between them. Herrmann and Mihaljek (2010) find that both country specific and global factors are statistically significant determinants of bilateral crossborder bank lending. As discussed in our literature review, Cerutti, Claessens and Laeven (2015) analyze cross-border bank credit spillovers from macroprudential policy measures within a gravity framework and find evidence of credit leakage effects, as do Reinhart and Sowerbutts (2015).

In our adaptation of the gravity model of international trade to bilateral cross-border bank credit $C_{i, j, t}$ to recipient country $i$ from source country $j$, we assume that

$$
C_{i, j, t}=\frac{\left(C_{i, t}^{d}\right)^{\alpha_{1}}\left(C_{j, t}^{s}\right)^{\alpha_{2}}}{\left(D_{i, j, t}\right)^{\alpha_{3}}},
$$

where $C_{i, t}^{d}$ denotes bank credit demand in recipient country $i, C_{j, t}^{s}$ denotes cross-border bank credit supply in source country $j$, and $D_{i, j, t}$ denotes the financial distance between these two countries, where all parameters are positive. As specified, bank credit to recipient country $i$ from source country $j$ is directly proportional to domestic bank credit demand, as well as to foreign cross-border bank credit supply, and is inversely proportional to financial distance, which measures financial transaction costs and restrictions. Applying a logarithmic transformation to this assumed gravity relationship yields

$$
c_{i, j, t}=\alpha_{1} c_{i, t}^{d}+\alpha_{2} c_{j, t}^{s}-\alpha_{3} d_{i, j, t},
$$

where lower case letters denote the natural logarithms of their uppercase counterparts.

We assume that logarithmic bank credit demand in recipient country $i$ is increasing in logarithmic domestic nominal output $y_{i, t}$, is decreasing in the domestic nominal bank lending interest rate $i_{i, t}$, and is increasing in a logarithmic domestic real house price index $q_{i, t}$ according to linear regression model

$$
c_{i, t}^{d}=\mu_{i}+\phi_{1} y_{i, t}-\phi_{2} i_{i, t}+\phi_{3} q_{i, t}+v_{i, t},
$$

where all coefficients are positive, while $\mu_{i}$ is an intercept and $v_{i, t}$ is a disturbance term. As specified, bank credit demand is increasing in the nominal volume of transactions, proxied by nominal output, and is decreasing in the cost of bank credit, as captured by the nominal bank lending interest rate, adjusted for a financial accelerator mechanism dependent on a real house price index, an increase in which loosens collateral constraints and raises leverage.

Furthermore, we assume that logarithmic cross-border bank credit supply in source country $j$ is decreasing in logarithmic domestic bank credit demand according to linear regression model

$$
c_{j, t}^{s}=\mu_{j}-\theta_{1} c_{j, t}^{d}+v_{j, t},
$$


where all coefficients are positive, while $\mu_{j}$ is an intercept and $v_{j, t}$ is a disturbance term. Under this specification, domestic borrowing partially crowds out cross-border lending by domestic banks.

Finally, we assume that the logarithmic financial distance between recipient country $i$ and source country $j$ depends on time invariant factors such as their geographical proximity, as well as on time varying factors proxied by a variety of indices, according to linear regression model

$$
\begin{aligned}
& d_{i, j, t}=\mu_{i, j}-\delta_{1} F M D_{i, t}-\delta_{2} F M D_{j, t}+\delta_{3} C F R_{i, t}+\delta_{4} C F R_{j, t} \\
& -\delta_{5} F X R_{i, t}-\delta_{6} F X R_{j, t}+\delta_{7} \sum_{s=1}^{t} I_{i, s}^{F C}+\delta_{8} \sum_{s=1}^{t} I_{j, s}^{F C} \pm \delta_{9} \sum_{s=1}^{t} I_{i, s}^{k^{+/-}} \pm \delta_{10} \sum_{s=1}^{t} I_{j, s}^{k^{+/-}}+v_{i, j, t},
\end{aligned}
$$

where all coefficients are positive, while $\mu_{i, j}$ is an intercept and $v_{i, j, t}$ is a disturbance term. As specified, financial distance is decreasing in indices of financial market development $F M D_{i / j, t}$, increasing in indices of capital flow restriction intensity $C F R_{i / j, t}$, and decreasing in indices of exchange rate flexibility $F X R_{i / j, t}$. Financial distance is also increasing in indices of financial stress, constructed by cumulating a financial crisis indicator variable $I_{i / j, t}^{F C}$ that equals one if the country is experiencing a financial crisis and zero otherwise. ${ }^{9}$

We are agnostic as to whether financial distance is increasing or decreasing in indices of macroprudential policy tightness - constructed by cumulating our instrument type-specific macroprudential policy tightening or loosening measure index $I_{i / j, t}^{k^{+/}}$. In fact, estimating the sign and statistical significance of the coefficients of our macroprudential policy tightness indices is the focus of our empirical analysis.

Substituting cross-border bank credit supply function (4) and financial distance function (5) into gravity model (2), and applying the ordinary difference operator $\Delta$ to obtain a specification for the growth rate of directional bilateral cross-border bank credit $\Delta c_{i, j, t}$, yields reduced-form panel linear regression model

$$
\begin{aligned}
& \Delta c_{i, j, t}=\beta_{i, j}+\beta_{t}+\beta_{1} \Delta c_{i, t}^{d}+\beta_{2} \Delta c_{j, t}^{d}+\beta_{3} \Delta F M D_{i, t}+\beta_{4} \Delta F M D_{j, t}+\beta_{5} \Delta C F R_{i, t} \\
& +\beta_{6} \Delta C F R_{j, t}+\beta_{7} \Delta F X R_{i, t}+\beta_{8} \Delta F X R_{j, t}+\beta_{9} I_{i, t}^{F C}+\beta_{10} I_{j, t}^{F C}+\beta_{11} I_{i, t}^{k^{+/-}}+\beta_{12} I_{j, t}^{k^{+/-}}+\varepsilon_{i, j, t},
\end{aligned}
$$

where $\beta_{i, j}$ is a pairwise fixed effect and $\beta_{t}$ is a time fixed effect, while $\varepsilon_{i, j, t}$ is an error term. Our underlying theoretical framework implies parameter restrictions $\beta_{i, j}=0, \beta_{t}=0$, $\beta_{1}=\alpha_{1}, \beta_{2}=-\alpha_{2} \theta_{1}, \beta_{3}=\alpha_{3} \delta_{1}, \beta_{4}=\alpha_{3} \delta_{2}, \beta_{5}=-\alpha_{3} \delta_{3}, \beta_{6}=-\alpha_{3} \delta_{4}, \beta_{7}=\alpha_{3} \delta_{5}, \beta_{8}=\alpha_{3} \delta_{6}$,

\footnotetext{
${ }^{9}$ The financial market development index is from Sahay and others (2015), with higher values indicating greater development. The capital flow restriction intensity index is from Fernández and others (2015), with higher values indicating greater restrictions. The exchange rate flexibility index is based on the de facto exchange rate regime classification in the IMF's Annual Report on Exchange Arrangements and Exchange Restrictions, with higher values indicating greater flexibility. The financial crisis indicator variable signals a banking, currency or sovereign debt crisis, based on Laeven and Valencia (2012).
} 
$\beta_{9}=-\alpha_{3} \delta_{7}, \beta_{10}=-\alpha_{3} \delta_{8}, \beta_{11}= \pm \alpha_{3} \delta_{9}$ and $\beta_{12}= \pm \alpha_{3} \delta_{10}$, as well as error structure $\varepsilon_{i, j, t}=\alpha_{2} \Delta v_{j, t}-\alpha_{3} \Delta v_{i, j, t}$.

\section{Estimation}

We estimate panel regression model (6) by instrumental variables, based on our dataset covering 64 countries, converted to the annual frequency over the period 2000 to 2014 . The dependent variable is the growth rate of directional bilateral cross-border bank credit, winsorized at the 5 percent level to remove outliers. All panel regression variable definitions and estimation results are reported in Tables 7 through 10 in Appendix II.

The specification of our panel regression model and the selection of instruments is guided by a variety of tests. We examine whether our explanatory variables are exogenous using the test due to Davidson and MacKinnon (1993). All of our explanatory variables robustly pass this exogeneity test, except for domestic bank credit growth in the source and recipient countries. We therefore correct for endogeneity bias in estimation using the growth rate of nominal output, the change in the nominal bank lending interest rate, and the growth rate of a real house price index in the recipient and source countries as instruments. In addition, we confirm that the latter variables are valid instruments - correlated with the endogenous explanatory variables and orthogonal to the error term - using the underidentification test of Kleibergen and Paap (2006) and the overidentification test associated with Hansen (1982).

Furthermore, we examine whether pairwise and time fixed effects are needed using likelihood ratio tests. We find that replacing the pairwise fixed effects with source and recipient country fixed effects results in a statistically significant deterioration in empirical fit, as does omitting time fixed effects. Finally, we examine whether a dynamic model specification is needed to account for persistence, despite using annual data. We find that a dynamic model specification does not pass the overidentification test for any reasonable lag order and therefore favor a static model specification.

The estimated coefficients of the macrofinancial control variables in our panel regression model support or are not inconsistent with our gravity model of directional bilateral crossborder bank credit growth. We find strong evidence that higher domestic credit growth in recipient countries is associated with higher growth in cross-border borrowing from foreign banks. In addition, we find strong evidence that greater exchange rate flexibility in recipient countries is associated with higher growth in cross-border borrowing from foreign banks. In parallel, we find weak evidence that greater exchange rate flexibility in source countries is associated with higher growth in cross-border bank lending to foreign borrowers. Finally, we find strong evidence that financial crises in recipient countries are associated with lower growth in cross-border borrowing from foreign banks. ${ }^{10}$

\footnotetext{
${ }^{10}$ Other coefficient estimates are statistically insignificant.
} 


\section{Inference}

Hypothesis tests within the framework of our estimated panel regression model indicate the existence of cross-border bank credit spillovers from macroprudential policy tightening and loosening measures using liquidity and sectoral instruments. Table 4 shows strong evidence of credit leakage effects from macroprudential policy tightening measures in recipient countries using liquidity instruments, associated with higher growth in cross-border borrowing from foreign banks at the 1 percent level. Moreover, we find moderate evidence of credit reallocation effects from tightening of sectoral instruments in source countries, associated with higher growth in cross-border lending by domestic banks to foreign borrowers at the 5 percent level. We also find moderate evidence of credit reallocation effects from macroprudential policy loosening measures in source countries using liquidity and sectoral instruments, with lower growth in domestic bank lending to foreign borrowers. However, we find little or no evidence of credit leakage or reallocation effects from macroprudential policy tightening or loosening measures using capital instruments.

Table 4. Hypothesis Test Results, Baseline Model Specification

\begin{tabular}{llll}
\hline \hline & & Cross-border reallocation & Cross-border leakage \\
\cline { 2 - 3 } & All instruments & & \\
\cline { 2 - 3 } Macroprudential & Capital & & + \\
policy tightening & Liquidity & + & + \\
& Sectoral & + \\
\cline { 2 - 3 } & Lenders & - \\
\hline \hline & Borrowers & \\
Macroprudential & All instruments & - \\
palicy loosening & Liquidity & - \\
& Sectoral & - \\
\cline { 2 - 3 } & Lenders & - \\
\hline \hline
\end{tabular}

Source: IMF staff estimates.

Note: Significance at the 1,5 and 10 percent levels is indicated by red, orange and yellow respectively.

\section{Robustness}

We check whether our statistical inference is robust to economically relevant changes in the coverage of our panel data set and the specification of our panel regression model. We estimate our baseline model specification using a European country subsample and repeat our hypothesis tests to determine if cross-border bank credit spillovers are regionally concentrated. We also estimate an interactive model specification, in which cross-border bank credit spillovers from macroprudential policy measures depend on capital account openness, and examine related hypotheses. 


\section{European Country Subsample}

Results using the European country subsample are broadly consistent with those obtained using the full sample. As reported in Table 5, we still find strong evidence of credit leakage effects from macroprudential policy tightening measures in recipient countries using liquidity instruments. Furthermore, we still find moderate evidence of credit reallocation effects from macroprudential policy tightening measures in source countries using sectoral instruments. However, we now find weak evidence of credit leakage effects from macroprudential policy tightening measures in recipient countries using sectoral instruments. We also find moderate evidence of credit reallocation effects from macroprudential policy tightening measures in source countries using liquidity instruments. Finally, we still find little or no evidence of credit leakage or reallocation effects from macroprudential policy tightening measures in recipient or source countries using capital instruments.

The estimated size of spillovers in the European country subsample is larger than for the full sample. Indeed, our estimated credit leakage and reallocation effects from macroprudential policy tightening measures using liquidity and sectoral instruments are about 50 and 100 percent larger, respectively. This comparison of the economic as opposed to statistical significance of the estimated coefficient on our macroprudential tightening measures indicates that credit spillovers from macroprudential policy measures are regionally concentrated. This result may reflect the high degree of harmonization in monetary policy, bank regulation, and legal frameworks in Europe.

Table 5. Hypothesis Test Results, Full versus European Country Sample

\begin{tabular}{|c|c|c|c|c|c|}
\hline & & \multicolumn{2}{|c|}{ Full Sample } & \multicolumn{2}{|c|}{ European Country Subsample } \\
\hline & & $\begin{array}{l}\text { Cross-border } \\
\text { reallocation }\end{array}$ & Cross-border leakage & $\begin{array}{l}\text { Cross-border } \\
\text { reallocation }\end{array}$ & Cross-border leakage \\
\hline \multirow{6}{*}{$\begin{array}{l}\text { Macroprudential } \\
\text { tightening }\end{array}$} & All instruments & & & + & + \\
\hline & Capital & & & & \\
\hline & Liquidity & & + & + & + \\
\hline & Sectoral & + & & + & + \\
\hline & Lenders & & + & & \\
\hline & Borrowers & + & & + & \\
\hline
\end{tabular}

Source: IMF staff estimates.

Note: Significance at the 1, 5 and 10 percent levels is indicated by red, orange and yellow respectively.

\section{Interactive Model Specification}

Under our interactive panel regression model specification, we interact our macroprudential policy tightening and loosening indices linearly with capital flow restriction intensity indices in the recipient and source countries. Intuitively, if cross-border bank credit leakage or reallocation effects exist, then they should be stronger for recipient or source countries with more open capital accounts. 
As reported in Table 6, we find strong evidence that credit leakage effects from macroprudential policy tightening measures using liquidity instruments are larger in recipient countries with more open capital accounts. In addition, we find weak evidence that credit reallocation effects from macroprudential policy tightening measures using sectoral instruments are larger in source countries with more open capital accounts. Furthermore, we find strong evidence that credit reallocation effects from macroprudential policy loosening measures using sectoral instruments are larger in source countries with more open capital accounts. Finally, we find little or no evidence that credit leakage or reallocation effects from macroprudential policy tightening or loosening measures using capital instruments are larger in recipient or source countries with more open capital accounts.

Table 6. Hypothesis Test Results, Interactive Model Specification

\begin{tabular}{|c|c|c|c|}
\hline \multirow{7}{*}{$\begin{array}{l}\text { Macroprudential } \\
\text { policy tightening with } \\
\text { more open capital } \\
\text { account }\end{array}$} & & \multirow[t]{2}{*}{ Cross-border reallocation } & \multirow{2}{*}{$\begin{array}{c}\text { Cross-border leakage } \\
+\end{array}$} \\
\hline & All instruments & & \\
\hline & Capital & & \\
\hline & Liquidity & & + \\
\hline & Sectoral & + & \\
\hline & Lenders & & + \\
\hline & Borrowers & + & \\
\hline & All instruments & - & \\
\hline Macroprudential & Capital & & \\
\hline policy loosening & Liquidity & & \\
\hline with more open & Sectoral & - & \\
\hline capital account & Lenders & & \\
\hline & Borrowers & - & \\
\hline
\end{tabular}

Source: IMF staff estimates.

Note: Significance at the 1,5 and 10 percent levels is indicated by red, orange and yellow respectively.

\section{Caveats}

The proportion of variation in directional bilateral cross-border bank credit growth explained by our estimated baseline panel regression model is low, with $R^{2}$ values of about 0.025 for the full sample and 0.050 for the European country subsample. Nevertheless, many of the coefficient estimates are statistically significant, including several of those related to the hypotheses under consideration.

\section{Structural Analysis}

We use an estimated dynamic stochastic general equilibrium (DSGE) model of the world economy to analyze cross-border macrofinancial spillovers from specific capital and sectoral macroprudential policy measures. Unlike our empirical analysis, this structural model-based simulation analysis estimates the economic significance of complete macroprudential policy spillover transmission mechanisms. However, it cannot distinguish between partial equilibrium credit leakage versus reallocation effects. In general equilibrium, only the net 
effect on bank credit of the behavioral responses of borrowers and lenders to a change in the financial regulatory environment is observed.

\section{A. Transmission Channels}

Our structural analysis is based on the Global Macrofinancial Model (GFM) documented in Vitek (2017). This estimated New Keynesian DSGE model covers 40 countries and features a range of nominal and real rigidities, extensive macrofinancial linkages with both bank and capital market based financial intermediation, and diverse spillover transmission channels. ${ }^{11}$

In the GFM, macrofinancial spillovers from macroprudential policy measures are transmitted from source to recipient countries via international trade, financial, and commodity price linkages:

- International trade linkages transmit private domestic demand and exchange rate shifts, induced by macroprudential policy measures in source countries, to recipient countries via export exposures.

- International financial linkages encompass cross-border bank lending, nonfinancial private sector borrowing, portfolio debt and equity exposures, and contagion effects. The most important international financial linkages for macroprudential policy spillover transmission are: (i) cross-border nonfinancial private sector borrowing exposures for measures imposed on banks; and (ii) cross-border bank lending exposures for measures imposed on firms. ${ }^{12}$

- Commodity price linkages matter only when source countries are large enough to significantly alter world energy and nonenergy commodity prices, affecting recipient countries via terms of trade shifts.

Observed bilateral bank lending and nonfinancial private sector borrowing exposures are generally small, relative to total bank lending and nonfinancial private sector borrowing. Therefore, they constitute narrow conduits for macrofinancial spillover transmission from foreign macroprudential policy measures. As depicted in Figure 4, they average only 0.2 and 0.4 percent across the 1560 directed country pairs covered by the GFM, respectively.

Despite this sparseness, there are many large bilateral bank lending and nonfinancial private sector borrowing exposures within the global banking network, with 1.1 and 1.3 percent of

\footnotetext{
${ }^{11}$ The countries covered by the GFM are Argentina, Australia, Austria, Belgium, Brazil, Canada, Chile, China, Colombia, the Czech Republic, Denmark, Finland, France, Germany, Greece, India, Indonesia, Ireland, Israel, Italy, Japan, Korea, Malaysia, Mexico, the Netherlands, New Zealand, Norway, the Philippines, Poland, Portugal, Russia, Saudi Arabia, South Africa, Spain, Sweden, Switzerland, Thailand, Turkey, the United Kingdom, and the United States.

${ }^{12}$ In the GFM, banks issue mortgage loans domestically, but issue corporate loans both domestically and crossborder, denominated in domestic currency.
} 
them exceeding 5 percent, respectively. These large exposures have the potential to transmit large macrofinancial spillovers from macroprudential policy measures in some countries to others.

Figure 4. Bilateral Bank Lending and Nonfinancial Private Sector Borrowing Exposures
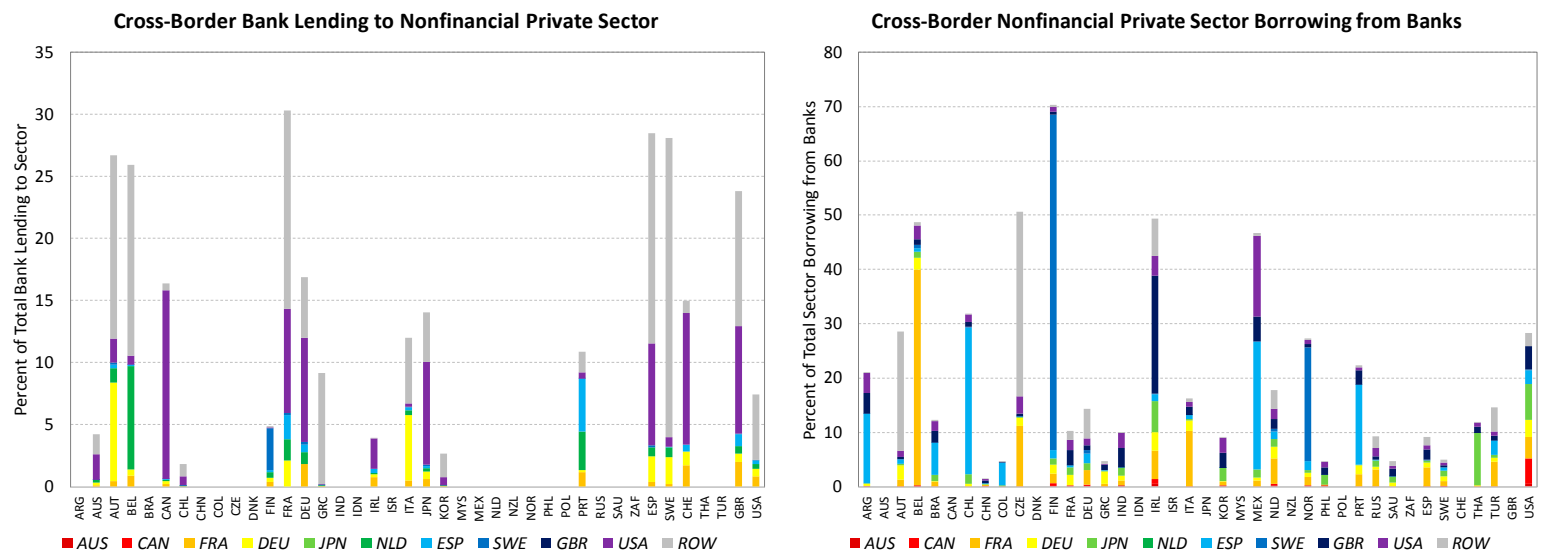

Source: IMF staff calculations.

Note: Derived from cross-border bank loans to the nonfinancial private sector, as reported by the BIS International Banking Statistics database on a consolidated ultimate risk basis for end-2014.

The application of cluster analysis reveals that bilateral bank lending and nonfinancial private sector borrowing exposures tend to be regionally concentrated, reflecting relationship banking. As depicted in Figure 5, on the lending side, the banking systems of the United Kingdom and United States have high network centrality, while those of France, Spain and Sweden are gatekeepers for regional networks. On the borrowing side, the nonfinancial private sectors of Austria, Belgium, France, Spain and Sweden all have multiple strong regional network connections. 
Figure 5. Cluster Analysis of Bilateral Lending and Borrowing Networks
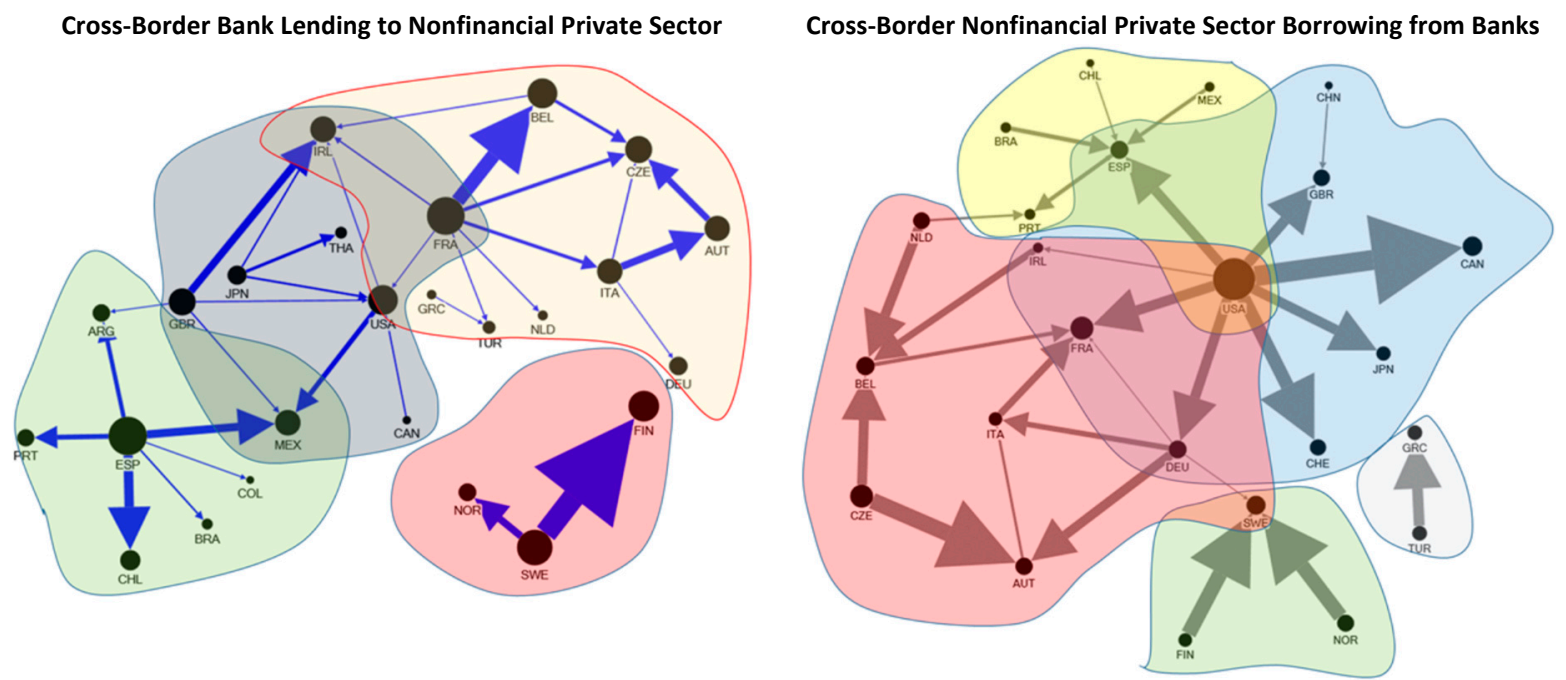

Source: IMF staff calculations.

\section{B. Simulation Results}

We quantify macrofinancial spillovers to recipient countries from unsystematic macroprudential policy measures in source countries with impulse responses to macroprudential policy shocks, identified as deviations from macroprudential policy rules. ${ }^{13}$ We allow monetary policy to respond endogenously to these macroprudential policy shocks. But we do not consider coordinated monetary and macroprudential policy measures to promote financial stability, which would have larger domestic macrofinancial effects and could generate larger spillovers.

We estimate macrofinancial spillovers with output and credit spillover coefficients, defined as the ratio of the peak impulse response of output or bank credit in the recipient country to that in the source country. For each of the macroprudential policy instruments, we explain the domestic and foreign macroprudential policy transmission mechanism operating in the GFM, with reference to the directed country pair example associated with the largest estimated output spillover. We then discuss our macrofinancial spillover estimation results for the 1560 directed country pairs under consideration.

\section{Countercyclical Capital Buffer}

In the GFM, the regulatory bank capital ratio requirement applicable to lending by domestic banks follows a countercyclical capital buffer (CCB) rule that responds inertially to bank credit growth, as well as to house and equity price growth. The CCB applies to the total

\footnotetext{
${ }^{13}$ Systematic macroprudential policy responses to variation in systemic risk indicators as prescribed by macroprudential policy rules would also be expected to generate macrofinancial spillovers, which will vary depending on the underlying source of variation in systemic risk.
} 
credit exposures of banks, consisting of domestic mortgage and corporate loan exposures, as well as foreign corporate loan exposures. This geographical coverage differs from the Basel Committee on Banking Supervision guidance that the CCB only apply to domestic credit exposures, which could reduce macrofinancial spillovers. A CCB shock is identified as a deviation from this CCB rule.

To explain macrofinancial spillovers from CCB adjustments, we consider the case of Sweden and Finland. As illustrated in Figure 6, an increase of the CCB by one percentage point in Sweden widens the spreads of the nominal mortgage and corporate loan rates over the nominal money market interest rate persistently, gradually raising the bank capital ratio to satisfy the higher regulatory requirement through the accumulation of retained earnings. This induces a persistent hump-shaped residential and business investment driven output contraction in Sweden, accompanied by a persistent hump-shaped inflation reduction and unemployment rate increase, reducing bank credit by up to 0.14 percent. The central bank cuts the nominal policy interest rate to raise inflation towards target and output towards potential—which falls due to physical capital decumulation — depreciating the currency in nominal and real effective terms. The fiscal balance deteriorates due to the fall in nominal output, while the current account balance improves despite a deterioration in the terms of trade due to import compression.

Given this CCB increase in Sweden, the nominal effective corporate loan rate rises almost as much in Finland, reflecting the high dependence of its nonfinancial private sector on Swedish bank loans. This induces an output contraction in Finland, accompanied by an inflation reduction and unemployment rate increase, reducing bank credit by up to 0.10 percent. This output loss from negative financial spillovers is amplified by negative trade spillovers, in the form of lower exports to Sweden. The fiscal balance deteriorates due to the fall in nominal output, while the current account balance improves due to import compression. The implied output and credit spillover coefficients are 0.99 and 0.67 , respectively. 
Figure 6. Impulse Responses to a Unit CCB Increase
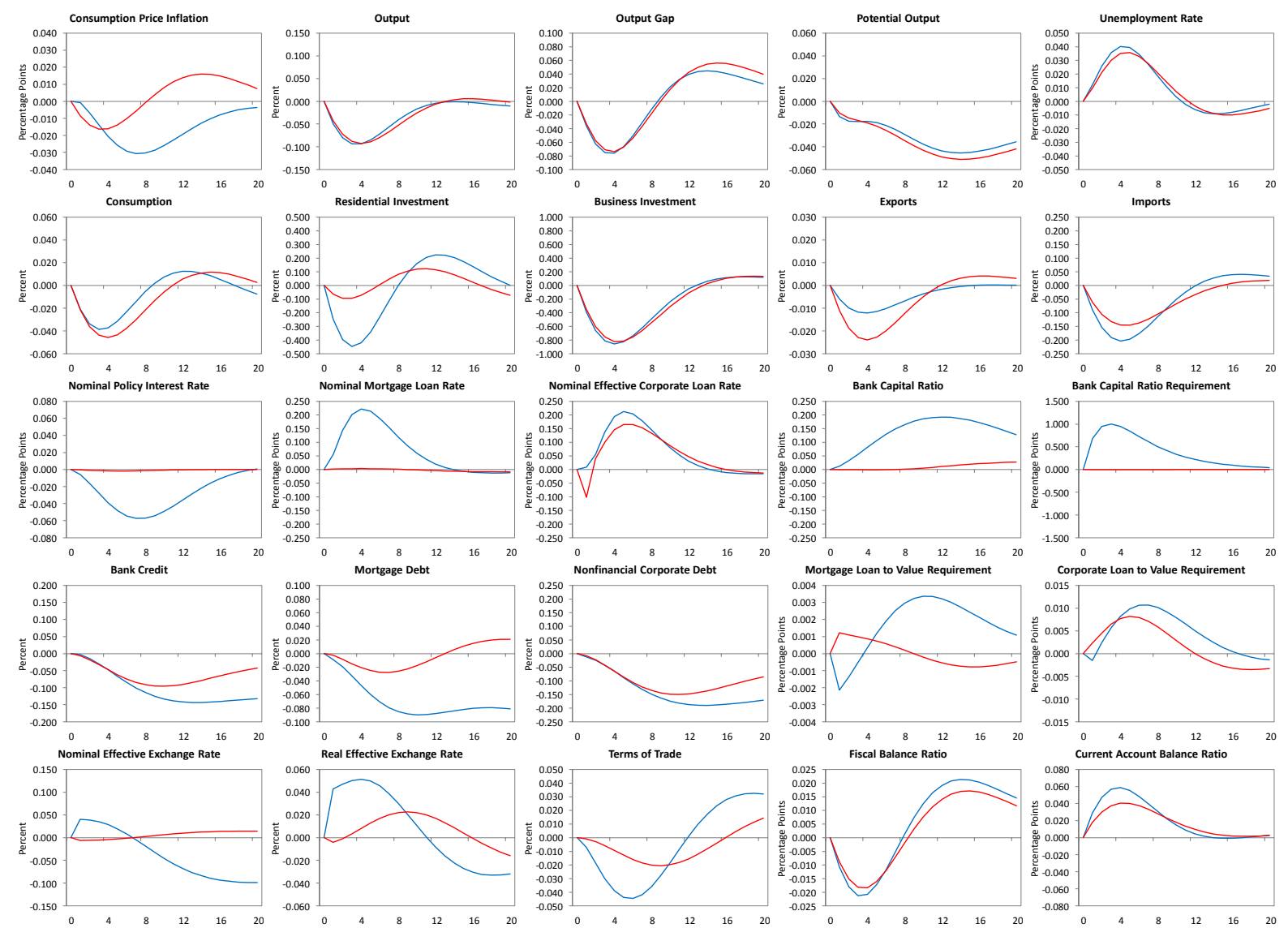

Source: IMF staff estimates.

Note: Depicts impulse responses for Sweden $\boldsymbol{m}$ and Finland $\boldsymbol{n}$ to a CCB shock in Sweden which raises its CCB by one percentage point. All variables are annualized, where applicable.

We estimate that macrofinancial spillovers from CCB adjustments are generally small worldwide in our sample, but are large for some country pairs. Indeed, as depicted in Figure 7, our estimated output spillover coefficients average only 0.008 across the 1560 directed country pairs under consideration, while our credit spillover coefficients average only 0.011 . But there are many large estimated macrofinancial spillovers, with 5.3 percent of our output and 4.9 percent of our credit spillover coefficients exceeding 0.05 . These large macrofinancial spillovers tend to be regionally concentrated, reflecting their strong dependence on bilateral export and nonfinancial private sector borrowing exposures. Indeed, the correlations of our estimated output and credit spillover coefficients with bilateral export exposures are 0.56 and 0.36 , while those with bilateral nonfinancial private sector borrowing exposures are 0.66 and 0.79 , respectively. 
Figure 7. Macrofinancial Spillovers from CCB Adjustments
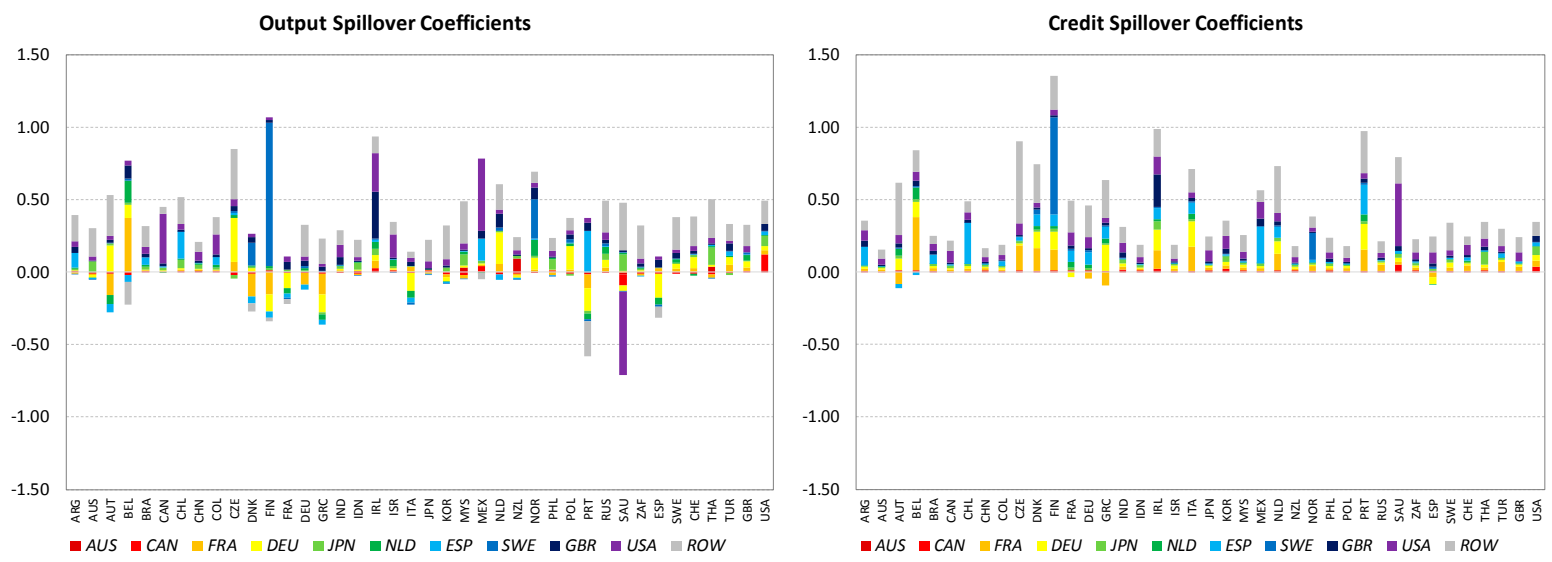

Source: IMF staff estimates.

Note: Depicts estimated output and credit spillover coefficients for all recipient countries with respect to selected source countries.

Our finding that macroeconomic spillovers from CCB increases are generally small worldwide is consistent with unpublished structural model based simulation analysis by the European Central Bank (ECB). Using a New Keynesian DSGE model of the Euro Area, they estimate that a 2.5 percentage point increase in the CCB in one member country generates peak output losses of 0.00 to 0.09 percent in other member countries.

\section{Mortgage Loan-to-Value Limit}

The regulatory mortgage loan-to-value ratio limit (MLTVL), applicable to borrowing by domestic developers from domestic banks, follows a rule in the GFM that responds inertially to mortgage debt growth and house price growth.

To illustrate spillovers from MLTVL adjustments, we consider the case of Germany and the

Czech Republic. As depicted in Figure 8, a reduction of the MLTVL by one percentage point in Germany decreases mortgage debt persistently in response to the tightening of this binding quantitative restriction, reducing bank credit by up to 0.53 percent. This induces an output decline in Germany, accompanied by an inflation reduction and unemployment rate increase. The ECB cuts the nominal policy interest rate to raise inflation towards target and output towards potential in the monetary union, depreciating the currency in nominal and real effective terms. The fiscal balance deteriorates due to the fall in nominal output, while the current account balance improves despite a deterioration in the terms of trade due to import compression.

This MLTVL reduction in Germany induces a persistent output contraction of at most 0.05 percent in the Czech Republic, accompanied by an inflation reduction and unemployment rate increase. The central bank cuts the nominal policy interest rate to raise inflation towards target and output towards potential - by more than in Germany given its 
greater monetary policy autonomy - depreciating the currency in nominal and real effective terms. The fiscal balance deteriorates due to the fall in nominal output, while the current account balance deteriorates reflecting lower exports to Germany. The implied output spillover coefficient is 0.37 .

Figure 8. Impulse Responses to a Unit MLTVL Reduction
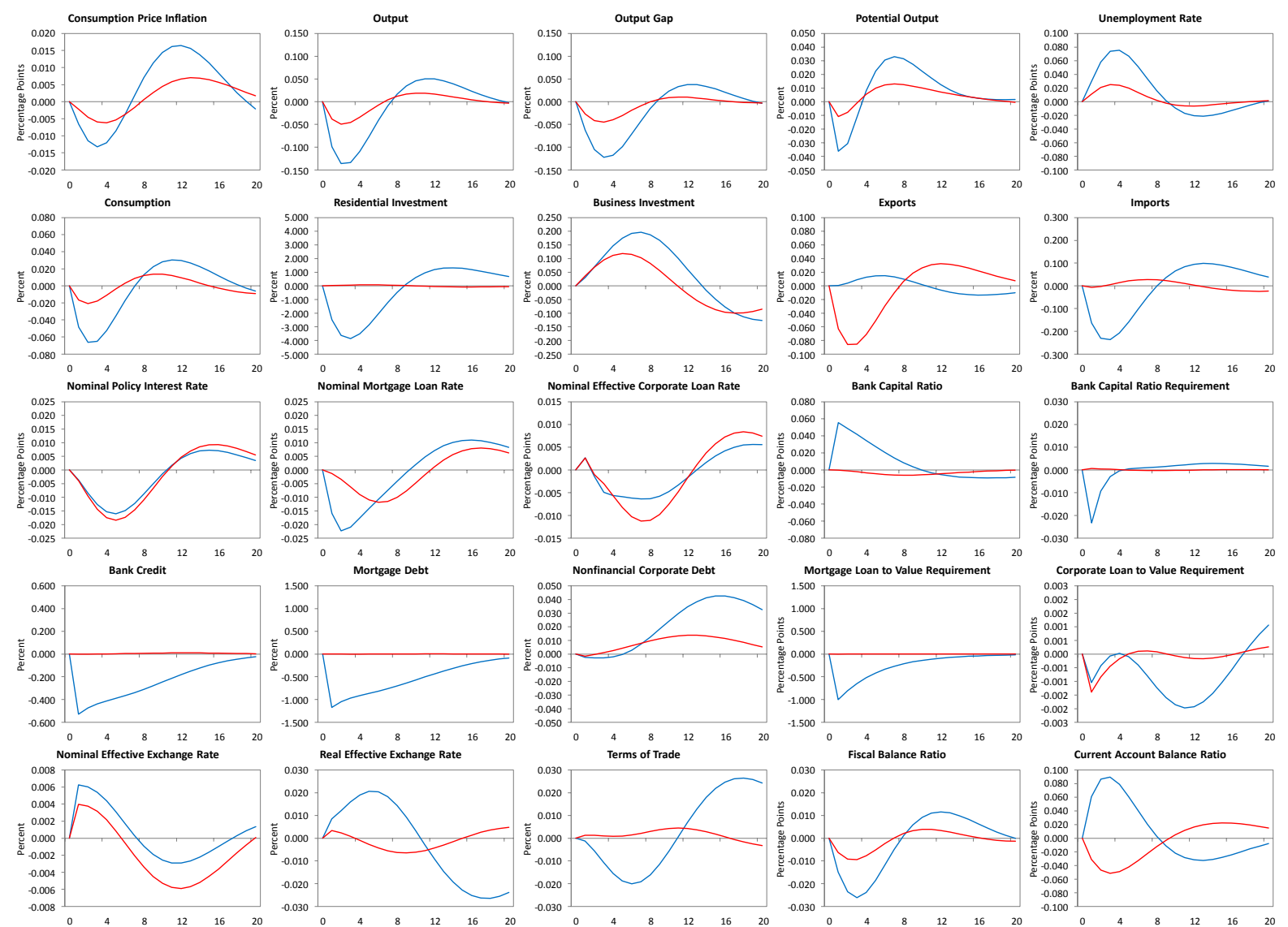

Source: IMF staff estimates.

Note: Depicts impulse responses for Germany $\mathbf{n}$ and the Czech Republic $\mathbf{n}$ to a MLTVL shock in Germany which reduces its MLTVL by one percentage point. All variables are annualized, where applicable.

As for the CCB, macrofinancial spillovers from MLTVL adjustments are generally small worldwide, but are large for some country pairs with strong linkages. As illustrated in Figure 9, our estimated output spillover coefficients average only 0.015 , while our credit spillover coefficients average only 0.001 . But there are some large estimated macroeconomic spillovers, with 6.8 percent of our output spillover coefficients exceeding 0.05 . These large macroeconomic spillovers tend to be regionally concentrated, reflecting a high correlation between our estimated output spillover coefficients and bilateral export exposures of 0.91 . 
Figure 9. Macrofinancial Spillovers from MLTVL Adjustments
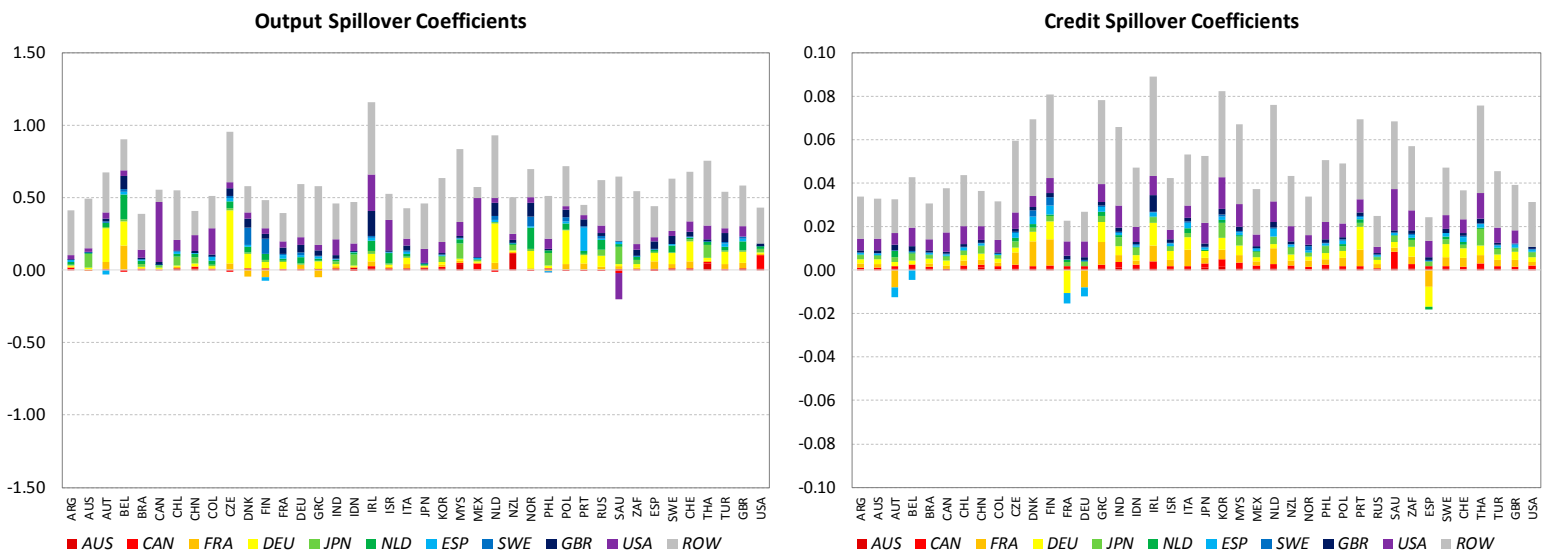

Source: IMF staff estimates.

Note: Depicts estimated output and credit spillover coefficients for all recipient countries with respect to selected source countries.

\section{Corporate Loan-to-Value Limit}

The regulatory corporate loan-to-value ratio limit (CLTVL), applicable to borrowing by domestic firms from domestic and foreign banks, follows a rule in the GFM that responds inertially to nonfinancial corporate debt growth and equity price growth.

We consider the hypothetical case of the United States and Mexico to illustrate spillovers from CLTVL changes. ${ }^{14}$ As depicted in Figure 10, in response to a one percentage point CLTVL reduction in the United States, nonfinancial corporate debt persistently decreases in response to the tightening of this binding quantitative restriction, reducing bank credit by up to 0.73 percent. This induces an output contraction, as well as an inflation reduction and unemployment rate increase. The central bank cuts the nominal policy interest rate to raise inflation towards target and output towards potential, depreciating the currency in nominal and real effective terms. This CLTVL reduction in the United States induces a persistent hump-shaped export driven output contraction in Mexico. The current account balance deteriorates reflecting lower exports to the United States, as well as lower energy and nonenergy commodity prices. The implied output spillover coefficient is 0.39 .

\footnotetext{
${ }^{14}$ The CLTVL has been rarely used in practice, and does not currently exist in the United States. But it may get used more frequently in the future, given heightened corporate debt related financial stability risks in many countries, and the trend towards greater macroprudential policy usage worldwide.
} 
Figure 10. Impulse Responses to a Unit CLTVL Reduction
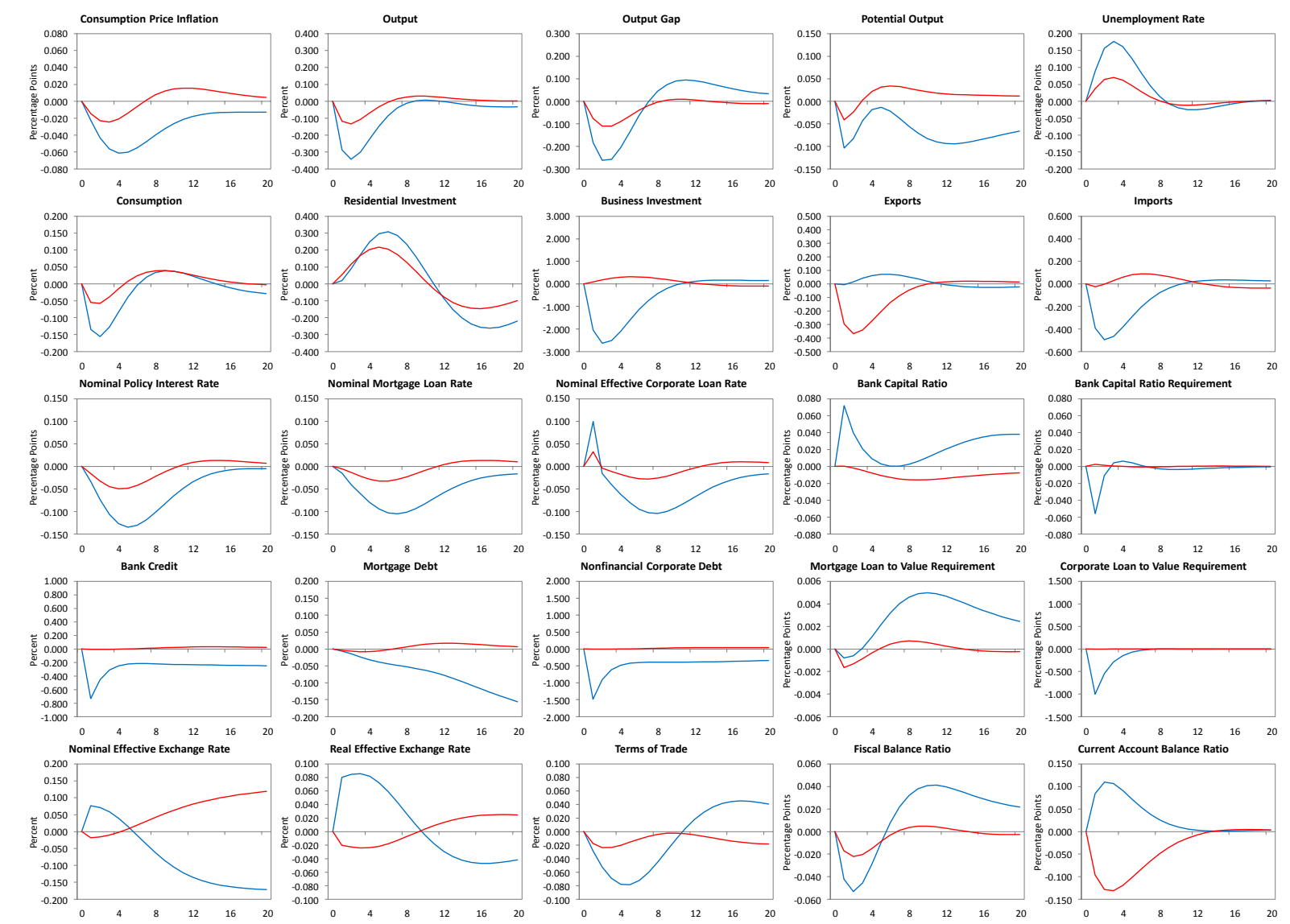

Source: IMF staff estimates.

Note: Depicts impulse responses for the United States $\mathbf{a}$ and Mexico $n$ to a CLTVL shock in the United States which reduces its CLTVL by one percentage point. All variables are annualized, where applicable.

Although macrofinancial spillovers from CLTVL changes are small worldwide, there are many large regionally concentrated estimated spillovers. Indeed, as illustrated in Figure 11, 6.0 percent of our output and 1.6 percent of our credit spillover coefficients exceed 0.05 . The correlations of our estimated output and credit spillover coefficients with bilateral export exposures are 0.87 and 0.45 , while those with bilateral bank lending exposures are 0.31 and 0.87 , respectively. 
Figure 11. Macrofinancial Spillovers from CLTVL Adjustments
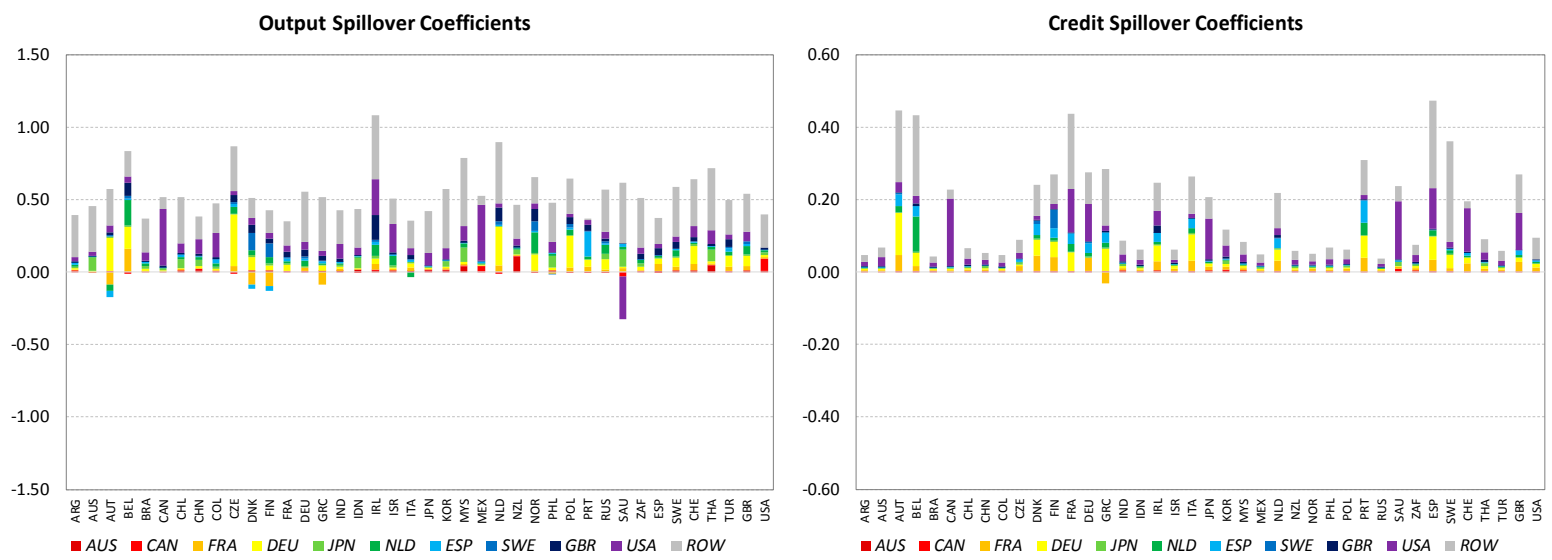

Source: IMF staff estimates.

Note: Depicts estimated output and credit spillover coefficients for all recipient countries with respect to selected source countries.

\section{Discussion}

While our model based simulation analysis indicates that macrofinancial spillovers from macroprudential policy measures using capital and sectoral instruments are generally small worldwide, it reveals that capital and sectoral instrument adjustments in some countries can have large macrofinancial spillovers to others. This result is to be expected, as most country pairs in our sample are weakly connected by trade and financial linkages, while important regionally concentrated linkages exist. In particular: (i) output and bank credit spillovers from CCB adjustments can be economically significant for recipient countries having high export or nonfinancial private sector borrowing exposures to source countries; (ii) output spillovers from MLTVL adjustments can be economically significant for recipient countries having high export exposures to source countries; and (iii) output and bank credit spillovers from CLTVL adjustments can be economically significant for recipient countries having high export or bank lending exposures to source countries.

\section{CONCLUSION}

Macroprudential policy has become part of the policy toolkit in many advanced and emerging market economies. Macroprudential policy measures taken to mitigate systemic risk in one regulatory jurisdiction can have macrofinancial effects on other jurisdictions. If these spillovers are significant, then policymakers should consider them when addressing systemic risks.

The empirical literature on the existence and importance of cross-border macroprudential policy spillovers reports mixed results. Several studies find that adjustments to liquidity or sectoral instruments statistically significantly affect cross-border bank credit, whereas adjustments to capital instruments do not. However, other studies contradict these results. 
This paper analyzes cross-border macrofinancial spillovers from a variety of macroprudential policy measures using, for the first time, a range of quantitative methods: nonparametric event study analysis, reduced-form panel regression analysis, and structural model based simulation analysis. Our event study and panel regression analyses find evidence of the existence of cross-border bank credit spillovers from sectoral and liquidity based macroprudential policy measures, but not from capital measures. This empirical evidence is stronger for tightening than for loosening measures, is distributed across credit leakage and reallocation effects, and is generally regionally concentrated. Consistent with these empirical results, our simulation analysis indicates that macrofinancial spillovers from sectoral instrument adjustments - namely the MLTVL and CLTVL — are generally small worldwide, but can be large among countries with high export or bank lending exposures.

Our simulation analysis also indicates that CCB adjustments have the potential to generate sizeable regional macrofinancial spillovers. Since the widespread use of the CCB as a macroprudential policy instrument is recent, our panel data set does not cover it. But future empirical analyses may reveal evidence of regionally concentrated cross-border bank credit spillovers from CCB adjustments as observations accumulate. 


\section{Appendix I. Case Studies}

To complement our empirical and structural analyses, we present two case studies illustrating how cross-border bank credit spillovers can undermine the effectiveness of macroprudential policy tightening measures. In particular, we consider the cases of Central and Southeastern Europe (CESEE) and the Baltic Countries during the build-up to the Global Financial Crisis (GFC).

\section{Central and Southeastern Europe}

During the build-up to the GFC, strong economic growth in Central Europe (the Czech Republic, Hungary, Poland and the Slovak Republic), and more prominently in Southeastern Europe (Bulgaria, Croatia and Romania), was accompanied by credit booms. Rapid credit growth coincided with rapid increases in asset prices, as well as household and corporate leverage. These credit booms were largely financed by cross-border loans, mainly from internationally active banks headquartered in selected countries in Advanced Europe (Austria, Belgium, Italy and Switzerland), often channeled through local subsidiaries or branches amidst competition for market share. The extraordinary growth in cross-border bank lending from advanced European economies to Central Europe, and more strikingly to Southeastern Europe, is depicted in Figure 12. Remarkably, these cross-border bank loans to Central Europe rose from about 10 to 30 percent of their GDP from 2002 to 2008, while those to Southeastern Europe rose from about 10 to 80 percent of their GDP.

These large capital inflows generated systemic risk in the CESEE countries, largely arising from currency mismatches on bank, household and nonfinancial corporate balance sheets. To mitigate this systemic risk, many CESEE countries took macroprudential policy tightening measures in the mid-2000s, designed to limit the rapid increase in foreign currency denominated bank lending and build resilience to it. These macroprudential policy tightening measures included: (i) raising risk weights on foreign currency denominated bank loans (Croatia, Poland and Serbia); (ii) tightening lending standards and raising loan-loss provisions (Romania); (iii) imposing marginal reserve requirements on excessive credit growth and external borrowing by banks (Bulgaria and Croatia); and (iv) imposing loan-tovalue and debt-service-to-income ratio limits (Bulgaria and Croatia).

These macroprudential policy tightening measures taken by the CESEE countries were partially effective at reducing credit growth, and strengthened banks' capital and liquidity buffers, enhancing their resilience to the GFC, as discussed in Lim and others (2011). However, they were partially circumvented through cross-sectoral and cross-border credit leakage effects, as credit intermediation by domestic banks migrated to domestic nonbanks, and was displaced by cross-border borrowing from foreign banks. For example, as macroprudential policy was tightened in Bulgaria and Croatia, borrowing from foreign banks accelerated rapidly, as discussed in Bakker and Gulde (2010). Meanwhile, borrowing from foreign banks in Poland was channeled through foreign branches not subject to domestic 
macroprudential policy. As these circumvention tactics became known, the authorities widened the regulatory perimeter and harmonized financial regulation, limiting these regulatory arbitrage opportunities.

Figure 12. Cross-Border Bank Loans from Advanced Europe to the CESEE Countries
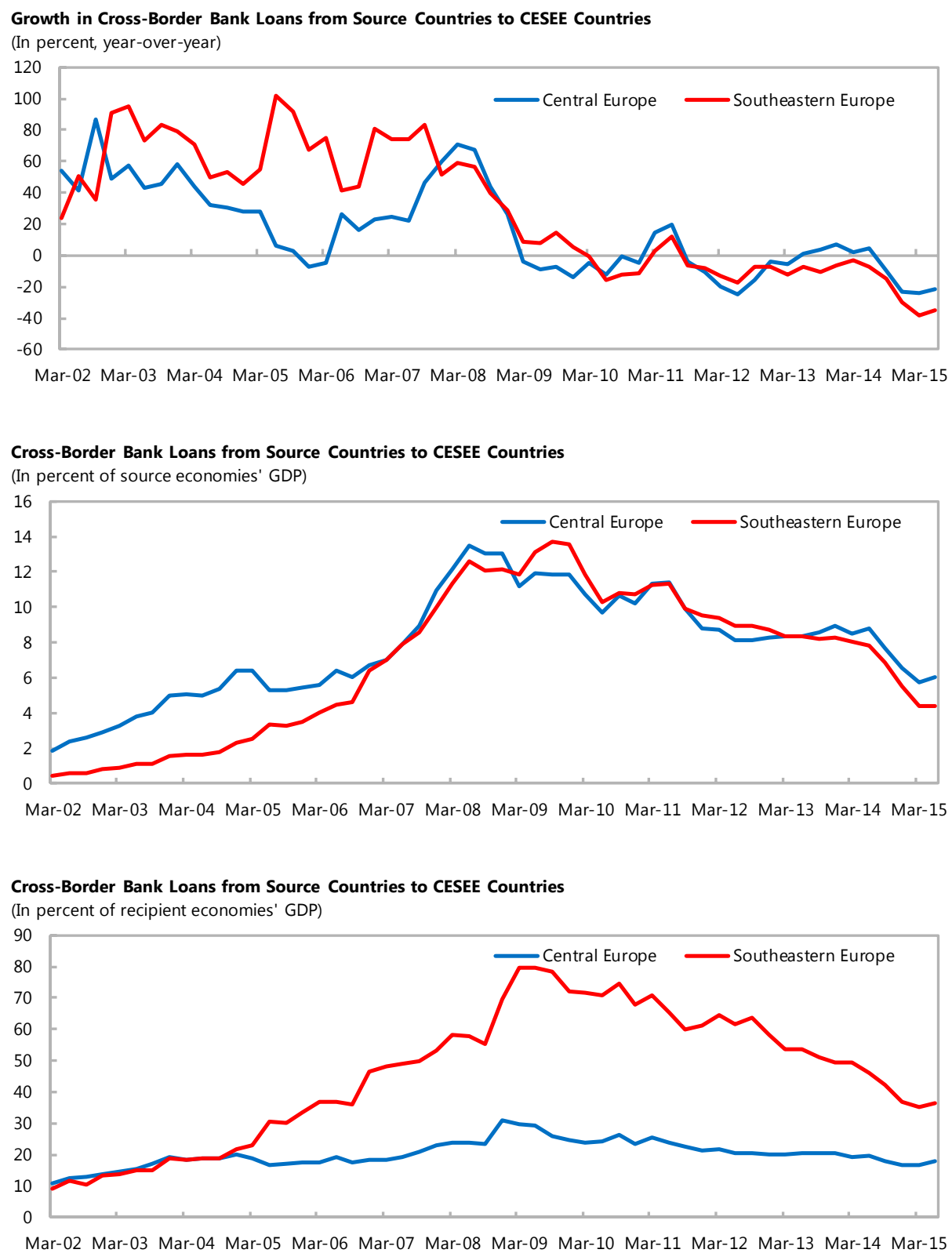

Sources: BIS International Banking Statistics database, Haver Analytics and IMF staff calculations.

Note: Source countries include Austria, Belgium, Italy and Switzerland. Central Europe includes the Czech

Republic, Hungary, Poland and the Slovak Republic. Southeastern Europe includes Bulgaria, Croatia and Romania.

There is also evidence that cross-border reallocation effects undermined the effectiveness of macroprudential policy tightening measures taken by the countries in Advanced Europe under consideration, during the build-up to the GFC. These macroprudential policy 
tightening measures were targeted at internationally active banks, and included higher capital requirements and stronger restrictions on their non-lending activities. As discussed in Ongena, Popov and Udell (2013), European banks searched for yield through greater risk taking in response, weakening their standards on lending to the CESEE countries.

\section{Sweden and the Baltic Countries}

During the decade prior to the GFC, the Baltic countries (Estonia, Latvia and Lithuania) experienced rapid economic growth accompanied by credit booms, as they transitioned from planned to market economies and deregulated their financial markets. These credit booms were largely financed by capital inflows from Swedish banks, largely channeled through local subsidiaries. Indeed, as depicted in Figure 13, Swedish bank loans to the Baltic countries increased from about 15 percent of their GDP in 2003 to about 100 percent by 2007.

These large capital inflows resulted in the accumulation of systemic risk in the Baltic countries, predominantly through large currency mismatches on household and nonfinancial corporate balance sheets, as well as substantially overvalued housing markets. To mitigate this systemic risk, the Baltic countries took a variety of macroprudential policy tightening measures, including: (i) raising risk weights on mortgage loans; (ii) raising reserve requirements; (iii) imposing loan-to-value and debt-service-to-income ratio limits on households (Latvia); and (iv) reducing the tax deductibility of mortgage interest payments (Estonia).

These macroprudential policy tightening measures taken by the Baltic countries were ineffective at reducing credit growth, but did strengthen banks' capital and liquidity buffers, enhancing their resilience to the GFC, as discussed in Sutt, Korju and Siibak (2011). Large cross-border bank credit spillovers, partially through credit leakage effects, were a major contributor to this macroprudential policy ineffectiveness. These credit leakage effects reflected: (i) high credit supply from Swedish banks exploiting highly profitable lending opportunities in the Baltic countries given their low cost access to global wholesale funding markets; (ii) circumvention of macroprudential policy tightening measures through crossborder borrowing from Swedish banks, largely channeled through local subsidiaries; and (iii) insufficient reciprocity in Sweden of macroprudential policy tightening measures taken in the Baltic countries, enabling local bank branches to exploit this regulatory arbitrage opportunity. 
Figure 13. Cross-Border Bank Loans from Sweden to the Baltic Countries
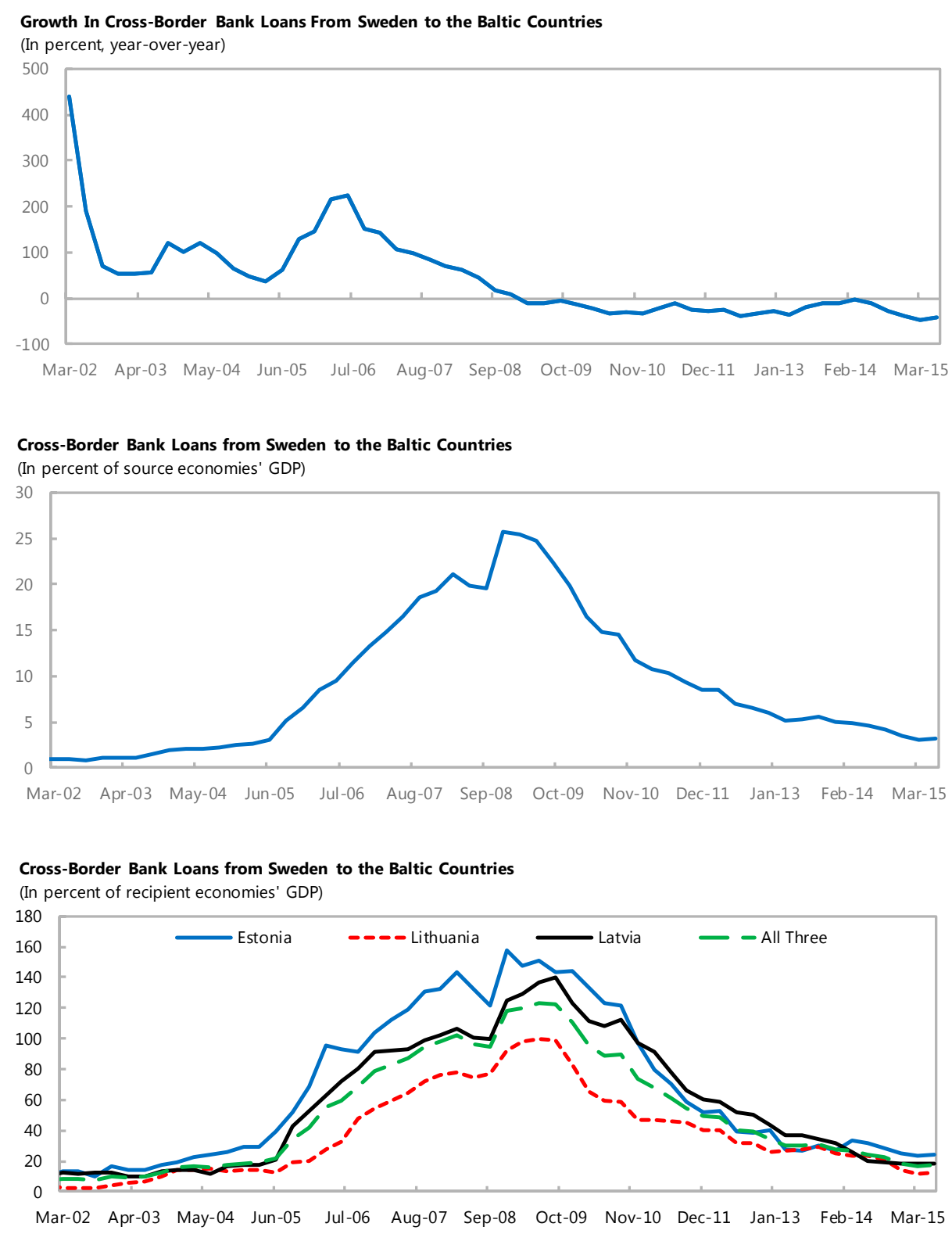

Sources: BIS International Banking Statistics database, Haver Analytics and IMF staff calculations. 


\section{Appendix II. Panel Regression Analysis}

\section{Table 7. Panel Regression Variable Definitions}

\begin{tabular}{|c|c|}
\hline \multicolumn{2}{|l|}{ Dependent variable } \\
\hline D_InTL_W & Growth rate of directional bilateral cross-border bank credit, winsorized at 5 percent level \\
\hline \multicolumn{2}{|c|}{ Explanatory variables } \\
\hline creditgr_recipient & Growth rate of domestic bank credit in recipient country \\
\hline creditgr_source & Growth rate of domestic bank credit in source country \\
\hline D.fdel_recipient & Change in financial market development index for recipient country \\
\hline D.fdel_source & Change in financial market development index for source country \\
\hline D.schkin_recipient & Schindler index of capital inflow controls in recipient country (higher value indicates more/tighter controls) \\
\hline D.schkout_source & Schindler index of capital outflow controls in source country (higher value indicates more/tighter controls) \\
\hline D.erri_recipient & Change in exchange rate regime in recipient country (higher value indicates more flexible regime) \\
\hline D.erri_source & Change in exchange rate regime in source country (higher value indicates more flexible regime) \\
\hline crisis_recipient & Dummy = 1 if banking/currency/sovereign crisis in recipient country, 0 otherwise \\
\hline crisis_source & Dummy = 1 if banking/currency/sovereign crisis in source country, 0 otherwise \\
\hline tallsum_recipient & Tightening of any macroprudential instrument in recipient country \\
\hline tallsum_source & Tightening of any macroprudential instrument in source country \\
\hline lallsum_recipient & Loosening of any macroprudential instrument in recipient country \\
\hline lallsum_source & Loosening of any macroprudential instrument in source country \\
\hline tcapital_recipient & Tightening of macroprudential capital instrument in recipient country \\
\hline tcapital_source & Tightening of macroprudential capital instrument in source country \\
\hline Icapital_recipient & Loosening of macroprudential capital instrument in recipient country \\
\hline Icapital_source & Loosening of macroprudential capital instrument in source country \\
\hline tliquidity_recipient & Tightening of macroprudential liquidity instrument in recipient country \\
\hline tliquidity_source & Tightening of macroprudential liquidity instrument in source country \\
\hline Iliquidity_recipient & Loosening of macroprudential liquidity instrument in recipient country \\
\hline Iliquidity_source & Loosening of macroprudential liquidity instrument in source country \\
\hline tsectoral_recipient & Tightening of macroprudential sectoral instrument in recipient country \\
\hline tsectoral_source & Tightening of macroprudential sectoral instrument in source country \\
\hline Isectoral_recipient & Loosening of macroprudential sectoral instrument in recipient country \\
\hline Isectoral_source & Loosening of macroprudential sectoral instrument in source country \\
\hline tborrower_recipient & Tightening of macroprudential policy on borrowers in recipient country \\
\hline tborrower_source & Tightening of macroprudential policy on borrowers in source country \\
\hline Iborrower_recipient & Loosening of macroprudential policy on borrowers in recipient country \\
\hline Iborrower_source & Loosening of macroprudential policy on borrowers in source country \\
\hline tlender_recipient & Tightening of macroprudential policy on lenders in recipient country \\
\hline tlender_source & Tightening of macroprudential policy on lenders in source country \\
\hline llender_recipient & Loosening of macroprudential policy on lenders in recipient country \\
\hline llender_source & Loosening of macroprudential policy on lenders in source country \\
\hline \multicolumn{2}{|l|}{ Instrumental variables } \\
\hline GDPGR_recipient & Growth rate of nominal gross domestic product in recipient country \\
\hline GDPGR_source & Growth rate of nominal gross domestic product in source country \\
\hline int_recipient & Change in nominal bank lending interest rate in recipient country \\
\hline int_source & Change in nominal bank lending interest rate in source country \\
\hline HPGR_recipient & Growth rate of real house price index in recipient country \\
\hline HPGR_source & Growth rate of real house price index in source country \\
\hline
\end{tabular}

Source: IMF staff calculations. 
Table 8. Panel Regression Estimation Results, Baseline Model Specification

\begin{tabular}{|c|c|c|c|c|c|c|}
\hline VARIABLES & $\begin{array}{c}(1) \\
\text { D_InTL_W }\end{array}$ & $\begin{array}{c}(2) \\
\text { D_InTL_W }\end{array}$ & $\begin{array}{c}\text { (3) } \\
\text { D_InTL_W }\end{array}$ & $\begin{array}{c}\text { (4) } \\
\text { D_InTL_W }\end{array}$ & $\begin{array}{c}(5) \\
\text { D_InTL_W }\end{array}$ & $\begin{array}{c}(6) \\
\text { D_InTL_W }\end{array}$ \\
\hline creditgr_recipient & $0.841^{* * *}$ & $0.890^{* * *}$ & $0.882^{* * *}$ & $0.884^{* * *}$ & $0.830^{* * *}$ & $0.879^{* * *}$ \\
\hline creditgr_source & 0.0222 & 0.00296 & 0.0625 & 0.0156 & 0.0590 & 0.0155 \\
\hline tallsum_recipient & 0.0267 & & & & & \\
\hline tallsum_source & 0.00585 & & & & & \\
\hline Iallsum_recipient & & 0.0215 & & & & \\
\hline lallsum_source & & $-0.0529 * * *$ & & & & \\
\hline tcapital_recipient & & & 0.0102 & & & \\
\hline tliquidity_recipient & & & $0.0996^{* * *}$ & & & \\
\hline tsectoral_recipient & & & 0.0298 & & & \\
\hline tcapital_source & & & -0.0375 & & & \\
\hline tliquidity_source & & & 0.00486 & & & \\
\hline tsectoral_source & & & $0.0486^{* *}$ & & & \\
\hline Icapital_recipient & & & & -0.0124 & & \\
\hline Iliquidity_recipient & & & & 0.0175 & & \\
\hline Isectoral_recipient & & & & 0.0369 & & \\
\hline Icapital_source & & & & 0.0209 & & \\
\hline Iliquidity_source & & & & $-0.0589^{* *}$ & & \\
\hline Isectoral_source & & & & $-0.0888^{* *}$ & & \\
\hline tlender_recipient & & & & & $0.0581 * *$ & \\
\hline tborrower_recipient & & & & & 0.0284 & \\
\hline tlender_source & & & & & -0.0264 & \\
\hline tborrower_source & & & & & $0.0461^{* *}$ & \\
\hline Ilender_recipient & & & & & & 0.0103 \\
\hline Iborrower_recipient & & & & & & 0.0374 \\
\hline Ilender_source & & & & & & $-0.0554^{* *}$ \\
\hline Iborrower_source & & & & & & $-0.0892 * *$ \\
\hline D.fdel_recipient & -0.379 & -0.394 & -0.400 & -0.386 & -0.341 & -0.383 \\
\hline D.fdel_source & 0.165 & 0.197 & 0.132 & 0.178 & 0.145 & 0.176 \\
\hline D.schkin_recipient & 0.178 & 0.180 & 0.175 & 0.179 & 0.168 & 0.171 \\
\hline D.schkout_source & -0.107 & -0.118 & -0.101 & -0.0932 & -0.105 & -0.110 \\
\hline D.erri_recipient & $0.0320^{* * *}$ & $0.0311^{* * *}$ & $0.0322^{* * *}$ & $0.0307^{* * *}$ & $0.0332^{* * *}$ & $0.0309^{* * *}$ \\
\hline D.erri_source & $0.0164^{*}$ & $0.0164^{*}$ & $0.0175^{* *}$ & $0.0170^{* *}$ & $0.0171^{* *}$ & $0.0164^{*}$ \\
\hline acrisis_d_source & -0.0243 & -0.0299 & -0.0208 & -0.0262 & -0.0225 & -0.0282 \\
\hline acrisis_d_recipient & $-0.159 * * *$ & $-0.158^{* * *}$ & $-0.150^{* * *}$ & $-0.160 * * *$ & $-0.156^{* * *}$ & $-0.159^{* * *}$ \\
\hline Observations & 12,144 & 12,144 & 12,144 & 12,144 & 12,144 & 12,144 \\
\hline R-squared & 0.027 & 0.024 & 0.026 & 0.025 & 0.029 & 0.026 \\
\hline Number of pairid & 1,344 & 1,344 & 1,344 & 1,344 & 1,344 & 1,344 \\
\hline
\end{tabular}

Source: IMF staff estimates.

Note: Significance at the 1, 5 and 10 percent levels on the basis of robust standard errors is indicated by ***,**, and * respectively. 
Table 9. Panel Regression Estimation Results, European Countries

\begin{tabular}{|c|c|c|c|c|c|c|}
\hline VARIABLES & $\begin{array}{c}(1) \\
\text { D_InTL_W }\end{array}$ & $\begin{array}{c}(2) \\
\text { D_InTL_W }\end{array}$ & $\begin{array}{c}\text { (3) } \\
\text { D_InTL_W }\end{array}$ & $\begin{array}{c}(4) \\
\text { D_InTL_W }\end{array}$ & $\begin{array}{c}(5) \\
\text { D_InTL_W }\end{array}$ & $\begin{array}{c}(6) \\
\text { D_lnTL_W }\end{array}$ \\
\hline creditgr_recipient & $0.871^{* * *}$ & $0.970^{* * *}$ & $0.668^{* * *}$ & $0.954^{* * *}$ & $0.856^{* * *}$ & $0.955^{* * *}$ \\
\hline creditgr_source & 0.105 & 0.237 & 0.122 & 0.245 & 0.174 & 0.230 \\
\hline tallsum_recipient & $0.0459^{*}$ & & & & & \\
\hline tallsum_source & $0.0628^{* *}$ & & & & & \\
\hline Iallsum_recipient & & 0.0335 & & & & \\
\hline lallsum_source & & $-0.0722^{* *}$ & & & & \\
\hline tcapital_recipient & & & -0.00776 & & & \\
\hline tliquidity_recipient & & & $0.146^{* * *}$ & & & \\
\hline tsectoral_recipient & & & $0.0609^{*}$ & & & \\
\hline tcapital_source & & & -0.0581 & & & \\
\hline tliquidity_source & & & $0.141^{* *}$ & & & \\
\hline tsectoral_source & & & $0.0920^{* *}$ & & & \\
\hline Icapital_recipient & & & & 0.0336 & & \\
\hline Iliquidity_recipient & & & & 0.0398 & & \\
\hline Isectoral_recipient & & & & -0.0338 & & \\
\hline Icapital_source & & & & 0.0676 & & \\
\hline Iliquidity_source & & & & -0.0647 & & \\
\hline Isectoral_source & & & & -0.0916 & & \\
\hline tlender_recipient & & & & & 0.0553 & \\
\hline tborrower_recipient & & & & & 0.0541 & \\
\hline tlender_source & & & & & 0.0241 & \\
\hline tborrower_source & & & & & $0.0829 * *$ & \\
\hline Ilender_recipient & & & & & & 0.0453 \\
\hline Iborrower_recipient & & & & & & -0.0273 \\
\hline Ilender_source & & & & & & -0.0470 \\
\hline Iborrower_source & & & & & & -0.0859 \\
\hline D.fdel_recipient & $-0.729^{* *}$ & $-0.742^{* *}$ & $-0.609 *$ & $-0.753^{* *}$ & $-0.676^{* *}$ & $-0.753^{* *}$ \\
\hline D.fdel_source & 0.0581 & 0.0707 & 0.0597 & 0.0543 & 0.0859 & 0.0600 \\
\hline D.schkin_recipient & 0.0447 & 0.0376 & 0.0594 & 0.0715 & 0.0554 & 0.0640 \\
\hline D.schkout_source & -0.0677 & -0.0752 & -0.0723 & -0.0375 & -0.0694 & -0.0670 \\
\hline D.erri_recipient & $0.0335^{* * *}$ & $0.0318^{* *}$ & $0.0296^{* * *}$ & $0.0312^{* *}$ & $0.0348^{* * *}$ & $0.0309^{* *}$ \\
\hline D.erri_source & 0.00445 & 0.00708 & 0.00363 & 0.00551 & 0.00582 & 0.00561 \\
\hline acrisis_d_source & -0.0286 & -0.0326 & -0.0337 & -0.0260 & -0.0235 & -0.0325 \\
\hline acrisis_d_recipient & $-0.141^{* * *}$ & $-0.138^{* * *}$ & $-0.150^{* * *}$ & $-0.136^{* * *}$ & $-0.136^{* * *}$ & $-0.136^{* * *}$ \\
\hline Observations & 5,120 & 5,120 & 5,120 & 5,120 & 5,120 & 5,120 \\
\hline R-squared & 0.053 & 0.042 & 0.069 & 0.044 & 0.054 & 0.044 \\
\hline Number of pairs & 499 & 499 & 499 & 499 & 499 & 499 \\
\hline
\end{tabular}

Source: IMF staff estimates.

Note: Significance at the 1, 5 and 10 percent levels on the basis of robust standard errors is indicated by ***,**, and * respectively. 
Table 10. Panel Regression Estimation Results, Interactive Model Specification

\begin{tabular}{|c|c|c|c|c|c|c|}
\hline VARIABLES & $\begin{array}{c}(1) \\
\text { D_InTL_W }\end{array}$ & $\begin{array}{c}(2) \\
\text { D_InTL_W }\end{array}$ & $\begin{array}{c}\text { (3) } \\
\text { D_InTL_W }\end{array}$ & $\begin{array}{c}(4) \\
\text { D_InTL_W }\end{array}$ & $\begin{array}{c}(5) \\
\text { D_InTL_W }\end{array}$ & $\begin{array}{c}(6) \\
\text { D_InTL_W }\end{array}$ \\
\hline creditgr_recipient & $0.852^{* * *}$ & $0.882^{* * *}$ & $0.889^{* * *}$ & $0.885^{* * *}$ & $0.861^{* * *}$ & $0.876^{* * *}$ \\
\hline creditgr_source & 0.0342 & 0.0168 & 0.0711 & 0.0469 & 0.0627 & 0.0441 \\
\hline tallsum_schkin_recipient & $0.0731^{*}$ & & & & & \\
\hline tallsum_schkout_source & -0.000827 & & & & & \\
\hline Iallsum_schkin_recipient & & 0.0633 & & & & \\
\hline lallsum_schkout_source & & $-0.0896^{* *}$ & & & & \\
\hline tcapital_schkin_recipient & & & -0.0167 & & & \\
\hline tliquidity_schkin_recipient & & & $0.183^{* * *}$ & & & \\
\hline tsectoral_schkin_recipient & & & -0.00449 & & & \\
\hline tcapital_schkout_source & & & 0.00573 & & & \\
\hline tliquidity_schkout_source & & & -0.0294 & & & \\
\hline tsectoral_schkout_source & & & $0.119^{*}$ & & & \\
\hline Icapital_schkin_recipient & & & & -0.119 & & \\
\hline Iliquidity_schkin_recipient & & & & 0.122 & & \\
\hline Isectoral_schkin_recipient & & & & -0.0910 & & \\
\hline Icapital_schkout_source & & & & -0.0716 & & \\
\hline Iliquidity_schkout_source & & & & -0.0299 & & \\
\hline Isectoral_schkout_source & & & & $-0.431^{* * *}$ & & \\
\hline tlender_schkin_recipient & & & & & $0.115^{* * *}$ & \\
\hline tborrower_schkin_recipient & & & & & -0.00146 & \\
\hline tlender_schkout_source & & & & & -0.0194 & \\
\hline tborrower_schkout_source & & & & & $0.122^{*}$ & \\
\hline Ilender_schkin_recipient & & & & & & 0.0901 \\
\hline Iborrower_schkin_recipient & & & & & & -0.0606 \\
\hline Ilender_schkout_source & & & & & & -0.0571 \\
\hline Iborrower_schkout_source & & & & & & $-0.415^{* * *}$ \\
\hline D.fdel_recipient & -0.367 & -0.382 & $-0.408^{*}$ & $-0.405^{*}$ & -0.366 & $-0.401^{*}$ \\
\hline D.fdel_source & 0.164 & 0.184 & 0.182 & 0.113 & 0.180 & 0.117 \\
\hline D.schkin_recipient & 0.157 & 0.172 & 0.155 & $0.233^{*}$ & 0.147 & 0.202 \\
\hline D.schkout_source & -0.107 & -0.102 & -0.109 & -0.0684 & -0.108 & -0.0696 \\
\hline D.erri_recipient & $0.0317^{* * *}$ & $0.0316^{* * *}$ & $0.0313^{* * *}$ & $0.0304^{* * *}$ & $0.0316^{* * *}$ & $0.0312^{* * *}$ \\
\hline D.erri_source & $0.0163^{*}$ & $0.0149 *$ & $0.0175^{* *}$ & $0.0140^{*}$ & $0.0173^{* *}$ & $0.0140^{*}$ \\
\hline acrisis_d_source & -0.0245 & -0.0266 & -0.0212 & -0.0276 & -0.0223 & -0.0279 \\
\hline acrisis_d_recipient & $-0.157^{* * *}$ & $-0.159^{* * *}$ & $-0.149 * * *$ & $-0.160 * * *$ & $-0.152^{* * *}$ & $-0.158^{* * *}$ \\
\hline Observations & 12,144 & 12,144 & 12,144 & 12,144 & 12,144 & 12,144 \\
\hline R-squared & 0.026 & 0.025 & 0.025 & 0.027 & 0.027 & 0.027 \\
\hline Number of pairs & 1,344 & 1,344 & 1,344 & 1,344 & 1,344 & 1,344 \\
\hline
\end{tabular}

Source: IMF staff estimates.

Note: Significance at the 1, 5 and 10 percent levels on the basis of robust standard errors is indicated by ***,**, and * respectively. 


\section{REFERENCES}

Aiyar, S., C. Calomiris, J. Hooley, Y. Korniyenko and T. Wieladek, 2014, "The International Transmission of Bank Capital Requirements: Evidence from the UK", Journal of Financial Economics, Vol. 113, pp. 368-382.

Akinci, O. and J. Olmstead-Rumsey, 2015, "How Effective are Macroprudential Policies? An Empirical Investigation", Board of Governors of the Federal Reserve System International Finance Discussion Paper, 1136.

Bakker, B. and A. Gulde, 2010, "The Credit Boom in the EU New Member States: Bad Luck or Bad Policies?", International Monetary Fund Working Paper, 130.

Bengui, J., 2012, "Macro-Prudential Policy Coordination and Global Regulatory Spillovers", Unpublished Manuscript.

Bergstrand, J., 1985, "The Gravity Equation in International Trade: Some Microeconomic Foundations and Empirical Evidence", The Review of Economics and Statistics, Vol. 67, pp. 474-481.

Buch, C. and L. Goldberg, 2016, "Cross-Border Prudential Policy Spillovers: How Much? How Important? Evidence from the International Banking Research Network", National Bureau of Economic Research Working Paper, 22874.

Cerutti, E., S. Claessens and L. Laeven, 2015, "The Use and Effectiveness of Macroprudential Policies: New Evidence", International Monetary Fund Working Paper, 61.

Cizel, J., J. Frost, A. Houben and P. Wierts, 2016, "Effective Macroprudential Policy: CrossSector Substitution from Price and Quantity Measures," International Monetary Fund Working Paper, 94.

Davidson, R. and J. MacKinnon, 1993, Estimation and Inference in Econometrics, Oxford University Press.

Deardorff, A., 1998, "Determinants of Bilateral Trade: Does Gravity Work in a Neoclassical World?", The Regionalization of the World Economy, edited by J. Frankel, University of Chicago Press.

Fahr, S. and D. Zochowski, 2015, "A Framework for Analysing and Assessing Cross-Border Spillovers from Macroprudential Policies”, European Central Bank Financial Stability Review, May. 
Fernández, A., M. Klein, A. Rebucci, M. Schindler and M. Uribe, 2015, "Capital Control Measures: A New Dataset”, International Monetary Fund Working Paper, 80.

Hansen, L., 1982, "Large Sample Properties of Generalized Method of Moments Estimators", Econometrica, Vol. 50, pp. 1029-1054.

Herrmann, S. and D. Mihaljek, 2013, "The Determinants of Cross-Border Bank Flows to Emerging Markets: New Empirical Evidence on the Spread of Financial Crises", Economics of Transition, Vol. 21, pp. 479-508.

Houston, J., C. Lin and Y. Ma, 2012, "Regulatory Arbitrage and International Bank Flows", The Journal of Finance, Vol. 67, pp. 1845-1895.

International Monetary Fund, 2014a, "Staff Guidance Note on Macroprudential Policy", International Monetary Fund Staff Guidance Note.

International Monetary Fund, 2014b, "Staff Guidance Note on Macroprudential Policy—Detailed Guidance on Instruments", International Monetary Fund Staff Guidance Note.

International Monetary Fund, Financial Stability Board, and Bank for International Settlements, 2016, "Elements of Effective Macroprudential Policies: Lessons from International Experience," Report to the G20.

Kleibergen, F. and R. Paap, 2006, "Generalized Reduced Rank Tests using the Singular Value Decomposition”, Journal of Econometrics, Vol. 127, pp. 97-126.

Laeven, L. and F. Valencia, 2012, "Systemic Banking Crises Database: An Update", International Monetary Fund Working Paper, 163.

Lim, C., F. Columba, A. Costa, P. Kongsamut, A. Otani, M. Saiyid, T. Wezel and X. Wu, 2011, "Macroprudential Policy: What Instruments and How to Use Them? Lessons from Country Experiences", International Monetary Fund Working Paper, 238.

Lim, C., I. Krznar, F. Lipinsky, A. Otani and X. Wu, 2013, "The Macroprudential Framework: Policy Responsiveness and Institutional Arrangements”, International Monetary Fund Working Paper, 166.

Ongena, S., A. Popov and G. Udell, 2013, "When the Cat's Away the Mice will Play: Does Regulation at Home Affect Bank Risk-Taking Abroad?", Journal of Financial Economics, Vol. 108, pp. 727-750. 
Portes, R. and H. Rey, 2005, "The Determinants of Cross-Border Equity Flows", Journal of International Economics, Vol. 65, pp. 269-296.

Reinhardt, D. and R. Sowerbutts, 2015, "Regulatory Arbitrage in Action: Evidence from Banking Flows and Macroprudential Policy”, Bank of England Working Paper, 546.

Sahay, R., M. Cihák, P. N’Diaye, A. Barajas, R. Bi, D. Ayala, Y. Gao, A. Kyobe, L. Nguyen, C. Saborowski, K. Svirydzenka and S. Yousefi, 2015, "Rethinking Financial Deepening: Stability and Growth in Emerging Markets", International Monetary Fund Staff Discussion Note, 8.

Sutt, A., H. Korju and K. Siibak, 2011, "The Role of Macro-Prudential Policies in the Boom and Adjustment Phase of the Credit Cycle in Estonia", World Bank Policy Research Working Paper, 5835.

Viñals, J. and E. Nier, 2014, "Collective Action Problems in Macroprudential Policy and the Need for International Coordination”, Banque de France Financial Stability Review, Vol. 18, pp. 39-46.

Vitek, F. (2017), "Policy, Risk and Spillover Analysis in the World Economy: A Panel Dynamic Stochastic General Equilibrium Approach", International Monetary Fund Working Paper, 89. 